\title{
Current Progress in the Therapeutic Options for Mitochondrial Disorders
}

\author{
Eliška KOŇǍ̌́́KOVÁ ${ }^{\mathbf{1}}$, Aleksandra MARKOVIĆ ${ }^{\mathbf{1}}$, Zuzana KORANDOVÁ ${ }^{\mathbf{1}}$, Josef $^{-}$ \\ HOUŠTĚK ${ }^{1}$, Tomáš MRÁČEK ${ }^{1}$
}

${ }^{1}$ Laboratory of Bioenergetics, Institute of Physiology, Czech Academy of Sciences, Prague, Czech Republic

Received June 13, 2020

Accepted October 2, 2020

Epub Ahead of Print November 2, 2020

\begin{abstract}
Summary
Mitochondrial disorders manifest enormous genetic and clinical heterogeneity - they can appear at any age, present with various phenotypes affecting any organ, and display any mode of inheritance. What mitochondrial diseases do have in common, is impairment of respiratory chain activity, which is responsible for more than $90 \%$ of energy production within cells. While diagnostics of mitochondrial disorders has been accelerated by introducing Next-Generation Sequencing techniques in recent years, the treatment options are still very limited. For many patients only a supportive or symptomatic therapy is available at the moment. However, decades of basic and preclinical research have uncovered potential target points and numerous compounds or interventions are now subjects of clinical trials. In this review, we focus on current and emerging therapeutic approaches towards the treatment of mitochondrial disorders. We focus on small compounds, metabolic interference, such as endurance training or ketogenic diet and also on genomic approaches.
\end{abstract}

\section{Key words}

Mitochondria • OXPHOS • Mitochondrial diseases • Gene therapy

- Mitochondrial donation

\section{Corresponding author}

Eliška Koňaříková and Tomáš Mráček, Laboratory of Bioenergetics, Institute of Physiology Czech Acad. Sci., Vídeňská 1083, 14220 Prague 4, Czech Republic. E-mail: eliska.konarikova@fgu.cas.cz, tomas.mracek@fgu.cas.cz.

\section{Introduction}

Mitochondria are ancient organelles fundamental for normal physiology and health (Henze and Martin 2003). They are responsible for various aspects of cellular metabolism. The oxidative phosphorylation system (OXPHOS), localized to the inner mitochondrial membrane, generates approximately $90 \%$ of cellular energetic currency, adenosine triphosphate (ATP) (Rich 2003). In addition, mitochondria are involved in a plethora of other functions - these include tricarboxylic acid cycle (i.e. Krebs cycle), urea cycle, gluconeogenesis and ketogenesis, enzymes of calcium signalling, adaptive thermogenesis, ion homeostasis, fatty acid oxidation, amino acid metabolism, lipid metabolism as well as physiological production of reactive oxygen species (ROS). Mitochondria also host individual steps from the biosynthesis of steroids, haem and iron-sulphur clusters and play a role in programmed cell death (Voet et al. 2013). Moreover, mitochondrial structure and function are under the control of two genomes, nuclear and mitochondrial. Unlike the nuclear genome, mitochondrial DNA (mtDNA) is maternally inherited and exists in up to several thousand copies per cell, depending on the cell type (Sciacco et al. 1994, Taylor and Turnbull 2005). Most of the sequence is coding and lacks an intron-exon structure, with the majority of genes located on one strand of the DNA molecule. Vast majority of 1500 mitochondrial proteins is encoded by nuclear genes. Mitochondrial DNA codes only for 13 structural 
subunits of OXPHOS system and a set of transfer and ribosomal RNAs that are essential for translation and mtDNA replication.

Mitochondrial disorders present the most heterogeneous group of metabolic diseases (Smeitink 2003, Thorburn 2004, Mayr et al. 2015). While individual mutations are very rare, as a whole group, they are among the most common forms of inborn errors of metabolism and inherited neurological disorders; it is estimated, that they affect at least 20 individuals per 100000 people (Gorman et al. 2016). To date, variants in more than 300 nuclear genes have been reported as disease causing (Stenton and Prokisch 2018, Stenton and Prokisch, 2020). The analysis of monogenic mitochondrial diseases has considerably enhanced general knowledge of the cellular pathophysiology of mitochondrial (dys)function. However, the diagnosis of mitochondrial diseases is challenging due to the large number of genes involved. Hence, in some genes, the mutations give rise to many common clinical syndromes. Unfortunately, the reverse is also true, some of the mitochondrial disease syndromes can have a very multifarious genetic background. As an example, Leigh syndrome, a severe neurological disorder has been reported to be caused by mutations in 75 genes located across the mitochondrial and nuclear genomes (Lake et al. 2016). The phenotypic spectrum of mitochondrial disorders is thus extremely broad and the clinical symptoms can affect any single tissue or organ or their combination at any age of onset with any mode of inheritance (Munnich and Rustin 2001).

The most commonly and severely affected tissues in mitochondriopathies are those with a high energy demand, such as the brain, retina, kidney, liver and skeletal or cardiac muscle. Hence, patients present with neurodegenerations, in many cases in combination with muscle weakness, cardiomyopathy, optic atrophy, or liver failure (Gorman et al. 2016, Suomalainen and Battersby 2018). This frequently makes mitochondriopathy a multisystemic disorder. Although, most mitochondrial disorders are progressive, there are many which manifest with a more stable course over decades, or even see amelioration of their symptoms (Koene and Smeitink 2011). The variety of possible clinical phenotypes is summarized in Figure 1 alongside the affected organs. Moreover, mitochondrial impairment is often observed in association with common disease, very often Parkinson's, Alzheimer's and Huntington's disease.
Within the last decades, enormous progress in understanding the molecular basis of mitochondrial disorders resulted in efficient screening and diagnosis. Unfortunately, this has not been reflected in the increased success in treatment of mitochondrial diseases. The number of approved drugs suitable for the majority of mitochondrial diseases is so far very restricted (Lightowlers et al. 2015). Still, numerous therapeutic options to interfere with disease progression have been explored in the past and some show promising results. They target various levels, ranging from lifestyle interventions through metabolic bypass to genome editing (Fig. 2).

In this review, we summarize currently available treatment approaches with focus on small compounds (see Fig. 3 for their molecular targets), manipulation of genomes and metabolic interference, such as endurance training or ketogenic diet. This review focuses on treatments which are currently already being evaluated in clinical trials, as well as the underlying preclinical research directed the bellow-mentioned topics. Numerous other approaches were explored on patient derived cellcultures or different animal models, but they are outside the scope of this review.

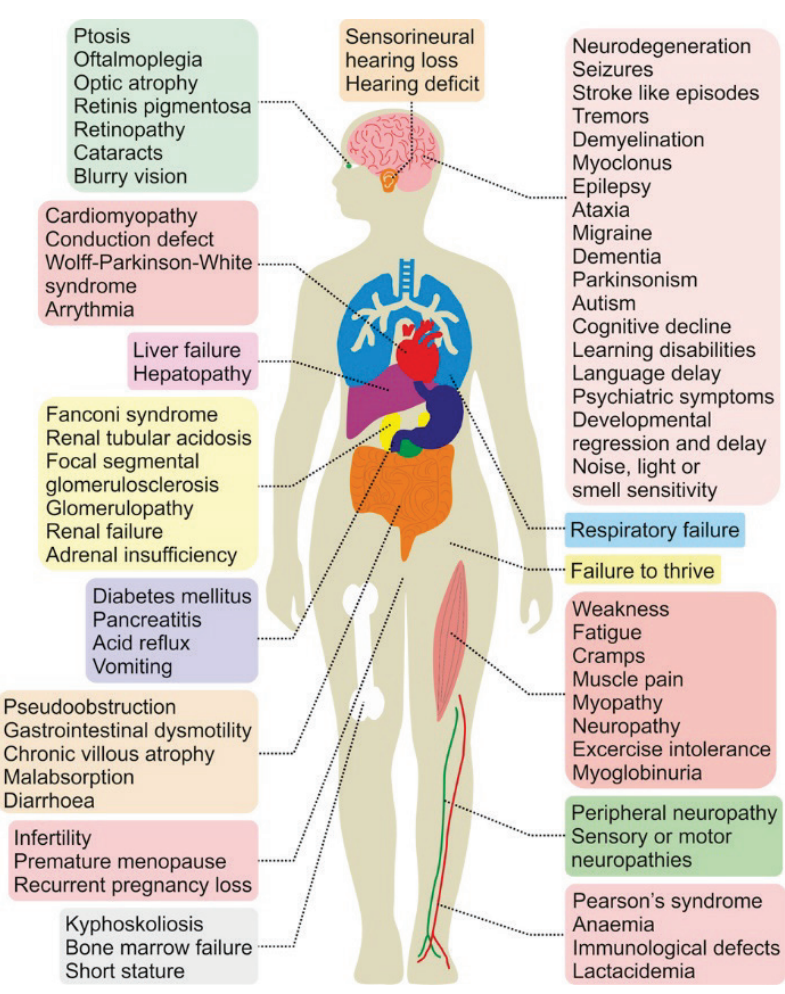

Fig. 1. Clinical symptoms of mitochondrial diseases. Mitochondrial disorders can manifest with a variety of clinical symptoms. They vary from very mild ones to very severe, mostly neurological difficulties. 


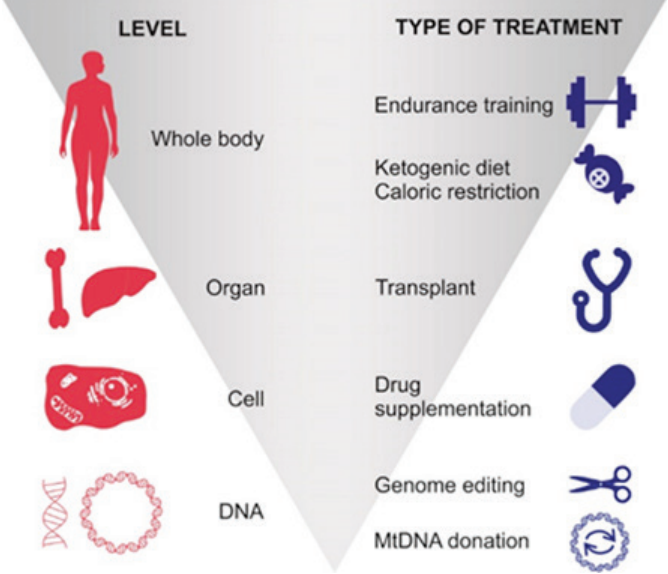

Fig. 2. Strategies to mitigate mitochondrial disease pathology. Combating mitochondrial disorders can take place on different levels. Vast majority of the treatment option is symptomatic. However, new methods based on genome editing present the future of cure for these genetic disorders.

\section{Small molecules}

The variety of phenotypes connected with mitochondrial diseases complicate the situation. The first choice in suspected mitochondrial disorders, is often a cocktail of nutritional supplements and vitamins, typically provided to the patient for a limited period of time (Chinnery and Turnbull 2001, Koene and Smeitink 2011, Pfeffer et al. 2012). The exact composition varies among clinical centres and is also dependent on the specific needs of individual patients. Most commonly the cocktail includes L-arginine (for metabolic strokes), coenzyme $\mathrm{Q}_{10}$ (in the form of ubiquinol or ubiquinone), creatine (to facilitate recycling of ATP), and L-carnitine (as an antioxidant and energy source) (Enns 2014).

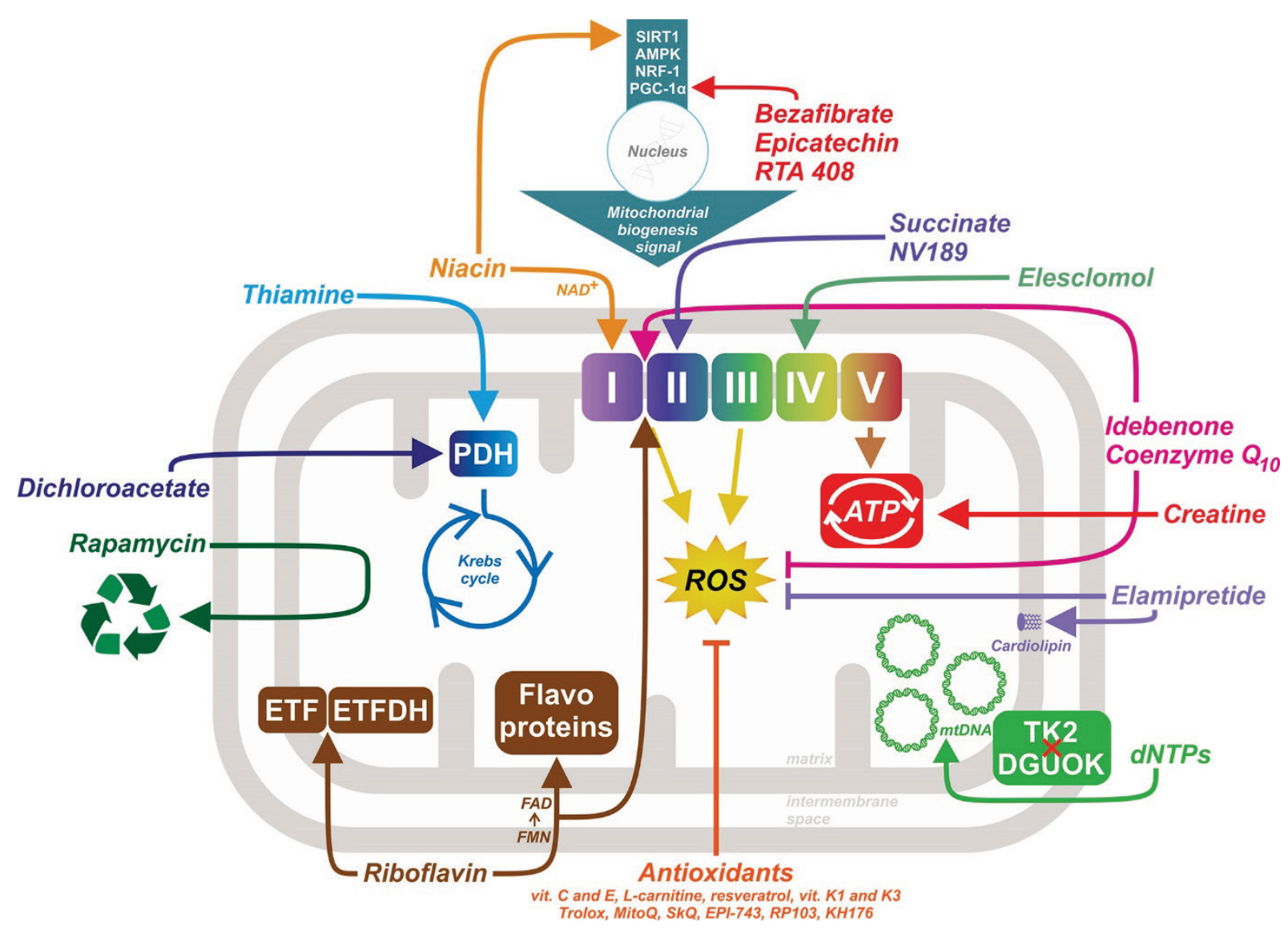

Fig. 3. Targets of individual small molecules. Points of interference with biochemical pathways are indicated by arrows for individual small molecules. See text for further details.

\section{Cofactors}

Mitochondria and especially the OXPHOS require organic and inorganic cofactors for their proper function. Many of the organic cofactors do have their precursors in vitamins such as biotin, niacin, riboflavin, or thiamine, while others are non-vitamin related (Coenzyme $\mathrm{Q}_{10}$, CoQ in short, or haem). In some cases, the genetic cause lies in enzymes involved in biosynthetic 
processes e.g. converting vitamins into the active cofactors or in CoQ biosynthesis. Here, supplementation can bypass a genetic defect and make such defects amenable to the treatment (Fig. 3). In that regard, they can be classified as treatable inborn errors of metabolism (Balasubramaniam et al. 2019). However, the same compounds can be also administered to other mitochondrial patients with the aim of improving flux through energy generating pathways. Since these cofactors are not connected to any harmful side-effects (Distelmaier et al. 2017), their administration can be considered as relatively safe and they can be involved in initial medication of suspected mitochondrial patients. Most notable examples of cofactors and their therapeutic use in mitochondrial disorders will be discussed in the following sections.

\section{Coenzyme $Q 10$}

Coenzyme $\mathrm{Q}_{10}$ is a crucial lipid-soluble electron carrier within OXPHOS and a potent antioxidant. The CoQ biosynthetic pathway consists of ten consecutive enzymatic reactions, with mutations described in each enzyme from this pathway (Awad et al. 2018). For these patients, CoQ supplementation represents a rational therapy approach, since the supplementation with CoQ may overcome its insufficient natural production (Hargreaves 2014, Awad et al. 2018, Potgieter et al. 2013). However, universal benefit of CoQ supplementation is inconsistent. In some cases the patients with CoQ synthesis deficiency responded well to CoQ supplementation with significant improvement of the disease course (Horvath 2012, Caglayan et al. 2019), but for example in patient with encephalomyopathy due to $C O Q 7$ mutation the response to $\mathrm{CoQ}$ treatment was poor and alternative approaches had to be explored (Kwong et al. 2019).

Regarding the general benefit of CoQ supplementation for different types of mutations, randomized double-blinded trial did not reveal the beneficial effect on any of the clinically relevant monitored variables (Glover et al. 2010). On the other hand, some case studies offer a more optimistic picture. For example, CoQ, pyruvate, and a $\beta$-adrenergic receptor blocker was successfully introduced in a pediatric patient with a mutation in acyl-CoA dehydrogenase 9 (ACAD9) leading to a complex I defect (Kadoya et al. 2019). Unassisted CoQ was also administered to patients with UQCRFS1 variants causing complex III deficiency (Gusic et al. 2020). One of the key factors for the successful usage of CoQ as a therapy for mitochondrial diseases is the timing of CoQ administration (Horvath 2012). Nevertheless, the most crucial is the bioavailability of the CoQ, which is limited and varies in different organs. This fuelled investigation of its artificial analogues with better solubility and thus bioavailability (Acosta et al. 2016).

\section{Idebenone}

Idebenone is one of the synthetic CoQ analogues used to treat mitochondrial disorders. Idebenone is a drug originally developed to treat Alzheimer's disease and similar cognitive defects (EMA, 2008). Later, clinical trials examined the use of Idebenone for patients with Friedreich's ataxia and Duchenne muscular dystrophy, however, usage in any of these settings has either not been successful or approved (Buyse et al. 2003, Di Prospero et al. 2007, Tonon and Lodi, 2008). Despite this, Idebenone was approved as a treatment for Leber's hereditary optic neuropathy (LHON) in Europe. In LHON patients, it shows discontinuation of further visual impairment (Klopstock et al. 2011, Klopstock et al. 2013, Rudolph et al. 2013, Lyseng-Williamson 2016). LHON syndrome is a common mitochondrial disease, characterized by a bilateral visual loss caused by defective complex I. In more than $95 \%$ of cases, it is caused by one out of three mtDNA mutations in ND4 (m.11778G $>\mathrm{A})$, ND6 (m.14484T $>\mathrm{C})$, or ND1 (m.3460G $>\mathrm{A})$ genes (Yu-Wai-Man et al. 2002). Idebenone can bypass malfunctioning complex I and feed electrons directly to complex III. It is also recapturing electrons outside the inner mitochondrial membrane to prevent reactive oxygen species production. For its antioxidant properties, Idebenone supplementation was successfully implemented also in a patient harbouring a mutation in $T X N 2$, coding for thioredoxin 2, a crucial mitochondrial antioxidant enzyme (Holzerova et al. 2016). Idebenone can easily be administered with fatty food and it is well absorbed into cells. However, less than $1 \%$ is able to pass through liver into circulation. This can be the main reason for its limited utility outside LHON cases.

\section{Thiamine}

Thiamine (vitamin $\mathrm{B}_{1}$ ) intake is beneficial in patients with a defective thiamine metabolism and cerebral thiamine transport through cellular and mitochondrial membranes (Ortigoza-Escobar et al. 2016). It was reported to prevent further neurological deterioration and metabolic crisis caused by mutations in 
thiamine transport related genes (Ortigoza-Escobar et al. 2016, Haack et al. 2014, Pomahačová et al. 2017). The identification of defects in thiamine uptake in infancy or early childhood may improve the prognosis, because that is largely dependent on the prompt initiation of thiamine treatment (Pérez-Dueñas et al. 2013). Early diagnosis may be achieved via biomarkers such as a decreased concentrations of free-thiamine in cerebrospinal fluid or of thiamine pyrophosphate in blood and muscle (MarcéGrau et al. 2019). Thiamine supplementation also helps to correct some other metabolic disorders, such as maple syrup urine disease and Leigh syndrome (Jauhari et al. 2017) as well as mitochondrial myopathy (Sato et al. 2000). The derivatives of thiamine play a role in several metabolic pathways, above all in the enzymatic reactions of sugar and amino acids catabolism or alcoholic fermentation. Thiamine also enhances the activity of pyruvate dehydrogenase, therefore increases production of reduced cofactors $\mathrm{NADH}$ and $\mathrm{FADH}_{2}$ (Gray et al. 2014).

\section{Riboflavin}

Another member of the vitamin B family is riboflavin, vitamin $\mathrm{B}_{2}$. It is a water-soluble precursor for flavin mononucleotide (FMN) and flavin adenine dinucleotide (FAD). Riboflavin or its derivatives take part in more than 100 enzymatic reactions including OXPHOS, fatty acid $\beta$-oxidation or the Krebs cycle (Lienhart et al. 2013). Riboflavin is synthetized in bacteria, plants and fungi; however, this ability has been lost in higher eukaryotes (Kaiser et al. 2002), therefore it must be obtained from food (Phillips and Shephard 1993). Supplementation is recommended for patients with impaired flavoproteome, where it is supposed to modulate mitochondrial electron transfer flux (Balasubramaniam et al. 2019). As an example, the riboflavin therapy was effective and mitigated symptoms in a deficiency of ACAD9, an FAD-containing enzyme (Haack et al. 2010, Repp et al. 2018), as well as in the case of FAD synthase deficiency (Olsen et al. 2016, Muru et al. 2019). Likewise, riboflavin supplementation was successfully used in multiple acyl-CoA dehydrogenase deficiency, typically caused by mutations in one of two genes coding for electron transferring flavoprotein ETFA or ETFB (Olsen et al. 2007, Olsen et al. 2016).

\section{Niacin}

The last example from the vitamin B family is vitamin $\mathrm{B}_{3}$, which serves as a precursor of nicotinamide adenine dinucleotide $\left(\mathrm{NAD}^{+}\right)$. It exists in several forms: nicotinic acid, nicotinamide (collectively termed niacin), or nicotinamide riboside (NR). $\mathrm{NAD}^{+}$(or NADH if reduced) acts as a coenzyme in redox reactions, many of them occurring in substrate catabolism leading to the synthesis of ATP, or as a donor of ADP-ribose (Billington et al. 2006). It was shown that vitamin $B_{3}$ supplementation might have a beneficial outcome in case of disruption of NAXE (also known as APOA1BP) (Kremer et al. 2016, Trinh et al. 2020). NAXE is an epimerase for $\mathrm{NAD}(\mathrm{P}) \mathrm{HX}$ that is a toxic metabolite. In one patient, the combination of vitamin $\mathrm{B}_{3}$ and $\mathrm{CoQ}$ supplementation brought continuous motor and cognitive improvement (Trinh et al. 2020).

Targeting $\mathrm{NAD}^{+}$metabolism was also attempted in general mitochondrial myopathies. In two mouse models of mitochondrial myopathy - deletor mouse (Khan et al. 2014) and Sco2 KO/KI mouse (Cerutti et al. 2014) - supplementation with NR delayed symptoms of the disease and improved OXPHOS function. Mouse studies favored NR as the optimal form of boosting $\mathrm{NAD}^{+}$, since it does not inhibit sirtuins (Belenky et al. 2007). However, human studies to date used either nicotinamide or nicotinic acid, probably for their proven safety record in humans. Initial case report dating to 1996 described nicotinamide treatment in MELAS (Mitochondrial encephalomyopathy, lactic acidosis, and stroke-like episodes, m.3243A $>$ G) patient, which boosted $\mathrm{NAD}^{+}$levels and decreased blood and urine lactate (Majamaa et al. 1996). A recent study in genetically varied group of patients with mitochondrial myopathy, then demonstrated systemic $\mathrm{NAD}^{+}$deficiency in patients, which was corrected by nicotinic acid supplementation. During a 10-month follow-up their mitochondrial biogenesis was increased and partial correction of muscle metabolome as well as increase in muscle strength were observed (Pirinen et al. 2020).

\section{Metal ions}

Several inorganic metal ions (e.g. copper, iron, magnesium, molybdenum, and zinc) also belong to the cofactor group. For cytochrome $c$ oxidase (COX) biogenesis, several mutations have been described in genes coding for proteins involved in copper delivery to the enzyme (SCO1, SCO2, COA6). In such cases, copper supplementation may also represent rational therapy. However, beneficial effect to $\mathrm{SCO} 2$ patient is limited to one described case-study using copper-histidine (Freisinger et al. 2004). On the other hand, recent 
preclinical studies identified Elesclomol as a highly efficient copper transporting pharmaceutical agent, which corrects $\mathrm{COX}$ deficiency in SCO2 patient cells (Soma et al. 2018). Since Elesclomol displayed favorable pharmacological profile in other clinical trials (O'Day et al. 2013), it may be considered for trial in human $\mathrm{SCO} 2$ defects.

\section{Nucleoside bypass therapy}

Nucleoside bypass therapy represents a specific type of a small molecule treatment. It is relevant for patients with Thymidine kinase 2 (TK2) deficiency. TK2 is responsible for phosphorylation of thymidine and deoxycytidine in order to produce deoxythymidine and deoxycytidine monophosphate (dTMP and dCMP), precursors of mitochondrial dNTPs. The lack of dNTPs then results in mtDNA instability and causes mtDNA depletion or multiple deletions. In preclinical mouse studies, supplementation of dTMP and dCMP delayed the disease onset, prolonged life span, and led to restoration of mtDNA levels as well as activities of OXPHOS complexes (Lopez-Gomez et al. 2017, Garone et al. 2014, Blázquez-Bermejo et al. 2019). First human trial was initiated as compassionate use program, based on the recommendations from $232^{\text {nd }}$ European Neuromuscular Centre workshop (Saada 2019, ENMC 2017). Compared to a natural course of the disease of untreated TK2 patients, first results indicate improved clinical measures for patients with early onset of symptoms. To the contrary, for those with the late onset of the disease, nucleoside supplementation only led to a stabilization of current symptoms (Domínguez-González et al. 2019). These results are now further elaborated in subsequent open-label long term clinical trial (NCT03639701).

In principle, analogous approach can be used in patients with deoxyguanosine kinase deficiency, enzyme responsible for proper function of mitochondrial purine nucleoside salvage pathway (El-Hattab et al. 2017).

\section{Antioxidants (Redox modulators)}

Mitochondrial disorders are often associated with increased levels of reactive oxygen species and vice versa. The elevation of oxidative stress can be caused either by a defective respiratory chain that is prone to leak electrons, or by a malfunction in the natural ROS removal. For a long time, ROS used to be seen only as dangerous agents that attack proteins, lipids and nucleic acids. However, in the last two decades, the importance of ROS in several signalling pathways has been described
(Jadiya and Tomar, 2020). Antioxidants in the broadest sense can correct the potential disbalance between ROS production and removal in mitochondrial patients (Holzerová and Prokisch, 2015). Due to their nature, antioxidant is 'any substance that delays, prevents, or removes oxidative damage to a target molecule' (Halliwell and Gutteridge, 2015). The naturally-derived antioxidants include vitamin $\mathrm{C}$ (ascorbic acid) and $\mathrm{E}$ (tocopherol), glutathione or CoQ (Marshall, 2014). Based on their properties, artificial antioxidants have been produced, e.g. Trolox (analogue of vit. E), Idebenone and MitoQ (analogues of CoQ), or SkQ (a cationic derivative of the plant plastoquinone). Also, compounds such as $\mathrm{N}$-acetylcysteine and $\alpha$-lipoic acid are able to boost the glutathione biosynthesis (Magalhães et al. 2016). The group of antioxidant drugs also includes L-carnitine, resveratrol, vitamins $\mathrm{K}_{1}$ and $\mathrm{K}_{3}$ (menadione), or commercially produced EPI-743 (a para-benzoquinone analogue), RP103 (cysteamine bitartrate, a promoter of glutathione synthesis) (Enns 2014, Russell et al. 2020) or KH176 (derivative of water-soluble form of vitamin E) (Koene et al. 2017, de Haas et al. 2017).

While some of these molecules are trialled for other conditions with supposed mitochondrial involvement (e.g. MitoQ and Alzheimer's disease (Russell et al. 2020)), their use in mitochondrial patients mostly lacks reliable evidence of a therapeutic effect. Some trials (NCT02023866 for RP103) were terminated for lack of efficacy, others, such as phase IIA clinical trial of KH176 in adult m.3243A>G patients (NCT02909400) did not achieve their primary outcome. However, KH176 testing still proved its safety and achieved positive effect on alertness and mood (Janssen et al. 2019). These effects are now further explored in a follow-up phase IIB trial, again on m.3243A $>\mathrm{G}$ patients (NCT04165239). Successful was also the use of Idebenone in TXN2 patient, where it acted as antioxidant (Holzerova et al. 2016). This is further discussed in the "Idebenone" section above.

\section{Elamipretide}

Elamipretide (also known as SS-31 peptide, Bendavia, or MTP-131) represents specific example of a compound falling under the antioxidants umbrella. Chemically, it is cell-permeable mitochondria-targeted antioxidant tetrapeptide with an alternating aromaticcationic structure. It targets cardiolipin on the inner mitochondrial membrane and improves coupling of the electron transport chain and thus phospholipid-dependent 
bioenergetics (Zhao et al. 2004). Elamipretide was proposed to have beneficial effects in numerous conditions. For example, neuroprotective effects of Elamipretide were demonstrated on mouse model of Alzheimer's disease where it caused reduction of synaptic activity and $A \beta$ levels (Reddy et al. 2017). Recent clinical research demonstrated significant improvement of mitochondrial function in cardiac cells through enhanced oxygen flux, CI and CIV activity and coupling of the supercomplexes after Elamipretide treatment (Chatfield et al. 2019). Use of Elamipretide showed cardioprotective effects and reduced myocardial infarction in experimental models of ischemiareperfusion injury (Cho et al. 2007), as well as in human biopsies following simulated ischemia reperfusion (Wijermars et al. 2016).

Elamipretide has also been tested in several consecutive clinical trials for patients with mitochondrial myopathy. Trials involved approximately 30 patients with diverse myopathies either due to nuclear or mtDNA mutations. While in a five day dose-escalation trial they managed to achieve improvement in a 6-minute walk test (primary outcome) (Karaa et al. 2018), this was narrowly missed in four week crossover trial (Karaa et al. 2020). Nevertheless, secondary outcomes, such as reported fatigue were significantly improved (Karaa et al. 2020), and neither of the studies reported significant side effects. This prompted phase III trial for Elamipretide (MMPOWER-3, NCT03323749), however, this was recently terminated, since double blind portion of the trial did not meet the primary end points. Yet another clinical trial of Elamipretide for mitochondrial diseases (NCT02693119) evaluates its utility for LHON patients.

\section{Agents enhancing mitochondrial biogenesis}

Another approach is to increase mitochondrial population utilizing inducers of mitochondrial biogenesis, which was effective in animal models of mitochondrial disorders (Cerutti et al. 2014, Peralta et al. 2016). General inducers of mitochondrial biogenesis include epicatechin, RTA 408 (omaveloxolone, potentially beneficial in case of Friedreich's ataxia), or bezafibrate. The last one is a PPAR agonist that can affect the PPAR/PCG-1 $\alpha$ pathway (Wu et al. 2020) leading to an increased mitochondrial mass, OXPHOS capacity, energy production and improvement in a supramolecular assembly and stability of OXPHOS complexes. Indeed, bezafibrate has shown promise as a disease modifying pharmaceutical agent in preclinical studies using both animal models (Dillon et al. 2012) and cell lines (Hofer et al. 2014). In patients with impairment in ACAD9, bezafibrate shows increase in complex I activity followed by improved respiration in patient cell lines (Repp et al. 2018). In a recent study, the effect of bezafibrate has been examined on mitochondrial function in fibroblasts derived from a patient carrying a dominant negative dynamin-1-like protein DNM1L mutation. It improved mitochondrial morphology, although causing a mild increase in ROS production at the same time (Douiev et al. 2020). Bezafibrate also controls the expression of many fatty acid oxidation (FAO) genes, thus is commonly used to treat dyslipidemia, and as a potential treatment for FAO disorders. It showed beneficial response in six patients with the myopathic form of carnitine palmitoyltransferase 2 (CPT-2) deficiency, where it markedly upregulated CPT-2, increased oxidation rates of the long-chain fatty acids, decreased muscle pain and increased physical activity in all treated patients (Bonnefont et al. 2010). Unfortunately, bezafibrate improved neither FAO nor exercise tolerance in patients with CPT-2 and very longchain acyl-CoA dehydrogenase deficiencies, possibly due to the high plasma insulin in patients, which markedly inhibited lipolysis and masked effects of bezafibrate (Ørngreen et al. 2014). Recent open-label clinical trial on six patients with mitochondrial myopathy caused by the m.3243A $>$ G MTTL1 mutation, shows expected induction of FAO, but minimal impact on markers of mitochondrial biogenesis (Steele et al. 2020). Importantly, in the same group of patients, they observed reduction in the number of complex IV-immunodeficient muscle fibres together with independent improvement of cardiac function. However, this was accompanied by an increase in serum biomarkers of mitochondrial disease and dysregulation of fatty acid and amino acid metabolism, indicating necessity for careful consideration of all outcomes for a long-term therapy (Steele et al. 2020).

\section{Rapamycin}

Rapamycin (also known as sirolimus) has a general effect on cellular fitness and thus can act in a similar fashion as agents enhancing mitochondrial biogenesis. Biochemically, rapamycin is a cellular inhibitor of mTOR (mammalian target of rapamycin) that has a broad effect on cell growth, metabolism, autophagy, lipid synthesis, transcription, translation, mitochondrial biogenesis, cell proliferation, and cell survival (Kaur and Sharma 2017). 
There is accumulating body of preclinical evidence for the utility of rapamycin in treatment of mitochondrial disorders. For example, at cellular level it was shown that rapamycin can activate mitophagy selectively in cells with pathogenic mtDNA mutation (Dai et al. 2014). Rapamycin was also demonstrated to ameliorate disease outcomes in four mouse models of mitochondrial disorder (Johnson et al. 2013, Khan et al. 2017, Siegmund et al. 2017, Ferrari et al. 2017, Civiletto et al. 2018). Moreover, administration of rapamycin in Deletor (Khan et al. 2017) and Ndufs4 KO (Leigh syndrome model) mice (Johnson et al. 2013) resulted in prolongation of lifespan. As a cautionary note, this is a general effect of the drug observed also in various models of ageing, so while beneficial, it may not be specific for models of mitochondrial dysfunction (Johnson and Kaeberlein 2016, Garone and Viscomi 2018). Although the precise mechanism of rescue remains to be elucidated, it seems that the stimulation of mitochondrial turnover, increase of autophagic flux and upregulation of lysosome biogenesis are probably responsible for rescuing mitochondrial disease phenotype via a promotion of metabolic reprogramming (Civiletto et al. 2018).

Just recently, two paediatric patients have been treated with a rapamycin analogue everolimus. A patient with Leigh syndrome showed sustained benefit, while clinical course of a patient with MELAS followed the known natural progression of the disease and resulted in an early death (Sage-Schwaede et al. 2019). Based on the preclinical observation, rapamycin is currently tested in paediatric patients with Leigh or Leigh-like syndrome (NCT03747328). Further trials might benefit from other molecules targeting mTOR pathway, but with different mechanisms of action than rapamycin (Lamming et al. 2013).

\section{Additional small compounds}

Next to the already mentioned compounds, several other drugs might be used to treat mitochondrial disorders. Examples are: (1) arginine or citrulline as precursors of nitric oxide whose lack causes stroke-like episodes; (2) creatine as a precursor of phosphocreatine serving as a source of high energy phosphate in metabolism; (3) succinate, a substrate of complex II (Parikh et al. 2009, Kerr, 2013, El-Hattab et al. 2017). More recently, also the synthetic cell-permeable analogue of succinate (NV189), has been shown to improve electron transport, membrane potential and ATP production in Leigh syndrome cell culture model (Ehinger et al. 2016). Second generation of succinate prodrugs (NV354) is currently being explored with the aim to bring them to clinical testing.

Some mitochondrial treatments aim to enhance OXPHOS function through increasing substrate availability. Dichloroacetate (DCA) is a structural analogue of pyruvate and is able to activate the pyruvate dehydrogenase through the inhibition of pyruvate dehydrogenase kinase. Therefore, DCA increases flux of pyruvate into mitochondria and boosts mitochondrial respiration and generation of ATP. DCA is generally well-tolerated in individuals with congenital lactic acidosis (Abdelmalak et al. 2013) and beneficial for alleviating lactic acidosis in mitochondrial diseases (Barshop et al. 2004). Since it causes peripheral nerve toxicity, DCA has not been shown as an efficient treatment in controlled clinical trial for MELAS patients (Kaufmann et al. 2006). A randomized controlled trial has been initiated recently, based on clinical and molecular genetic criteria in children with pyruvate dehydrogenase complex deficiency, i.e. the most common cause of congenital lactic acidosis. According to the authors of this clinical trial, DCA possesses an ability to increase both the catalytic activity and stability of the enzyme complex (NCT02616484). Moreover, a recent study also identified phenylbutyrate as an induced of PDH complex activity. Interestingly, effects of phenylbutyrate and DCA seem to be additive, suggesting a potential therapeutic direction (Ferriero et al. 2015). Phenylbutyrate may also substitute DCA in future trials, since it causes less harmful side effects than DCA (Stacpoole et al. 2019).

\section{Metabolic approach}

\section{Endurance training}

Mitochondrial disorders frequently lead to a muscular weakness, mitochondrial myopathy and low exercise capability (Taivassalo et al. 2003). This fuelled research into possible use of endurance exercise as a tool to modulate progress of the disease (Ziaaldini et al. 2017). At the molecular level, exercise works through stimulation of PGC- $1 \alpha$ and PGC-1 $\beta$ co-activators, which regulate mitochondrial biogenesis and oxidative metabolism (Handschin and Spiegelman, 2006). PGC- $1 \alpha / \beta$ upregulation then improves OXPHOS function in cells to compensate for respiratory chain defects (Srivastava et al. 2009). In patients, endurance exercise 
may delay progressive deterioration of their condition and has been shown to improve exercise capacity over time. It was reported that endurance training improved mitochondrial function in muscle biopsies through an increase in total content of mitochondria and their increased activity was visualized by staining of the CIV activity. Consequently, it facilitated improvement in maximal oxygen uptake, peripheral muscle strength, not to mention the overall improvement of clinical symptoms (Taivassalo et al. 2006, Safdar et al. 2016).

Preclinical evidence comes from several mouse models of mitochondrial dysfunction. For example, studies on mtDNA mutator mice demonstrated improvement of progeroid phenotype upon exercise training (Safdar et al. 2011). This was further elaborated in subsequent work, where depletion of $\mathrm{NAD}^{+}$and carnitine in the brain was observed and this was partially improved by training (Clark-Matott et al. 2015). Second studied model was Harlequin mouse $(\mathrm{Hq})$, with complex I deficiency due to reduced levels of AIF assembly factor (Bénit et al. 2008). Training program in these animals was started after the first signs of ataxia, at that time also myopathy was already present, which is a good simulation of the patient's situation. Aerobic and resistance training improved aerobic fitness, muscle strength and activity of OXPHOS complexes I, II and $\mathrm{V}$ in $\mathrm{Hq}$ mice. Training also slightly improved levels of proteins TFAM and PGC-1 (Fiuza-Luces et al. 2019).

Human studies have demonstrated that endurance training is safe and beneficial for the patients with metabolic myopathies caused by a large-scale mtDNA deletions (Porcelli et al. 2016, Taivassalo et al. 2006). Skeletal muscle function was also improved in patients with cardiomyopathy due to $\mathrm{m} .3243 \mathrm{~A}>\mathrm{G}$ (Bates et al. 2013). Maximal oxygen uptake $\left(\mathrm{VO}_{2 \max }\right)$, activity of citrate synthase and mtDNA quantity in muscle tissue increased after 12 weeks of exercise (Jeppesen et al. 2006). However, another smaller study showed that mutation load in mtDNA did not change during or after a training program (Jeppesen et al. 2009). A recent study with 12 patients with mtDNA mutations or deletions and with different clinical symptoms introduced special training program composed of aerobic training, resistance training and inspiratory muscle training for 8 weeks. This scheme was well tolerated and produced significant benefits in numerous indicators of their physical capacity, including aerobic power, muscle strength, and inspiratory muscle power (Fiuza-Luces et al. 2018).

In conclusion, endurance or resistant training seems to be favourable for the majority of patients with mitochondrial disorder, especially for those with mtDNA mutations or deletions (Murphy et al. 2008, Fiuza-Luces et al. 2018). Unfortunately, about $20 \%$ of those patients are suffering from exercise intolerance (Mancuso et al. 2012) and thus enrolment into exercise scheme has to be closely monitored.

\section{Ketogenic diet}

Ketogenic diet (KD), due to its numerous positive effects on metabolic and neurodegenerative disorders, became a promising therapeutic option. The idea of ketogenic agent administration in order to induce and sustain therapeutic ketosis has been present for decades (Miller and Dymsza, 1967). Generally, the ketogenic diet is a high-fat, low-protein, low-carbohydrate diet that has been employed for anticonvulsant effects on epileptic seizures (Zhang et al. 2018). The hallmark feature of KD treatment is the increased production of ketone bodies by the liver, reduced blood glucose and stimulation of mitochondrial $\beta$-oxidation followed with increased mitochondrial function. KD forces a switch to predominant metabolism of ketones rather than glucose, and enhances conversion of ketone bodies such as beta-hydroxybutyrate and acetoacetate into acetyl-CoA to support ATP production (Yudkoff et al. 2007). Today KD is used as treatment option in numerous conditions with suspected mitochondrial involvement, such as Huntington disease (Ruskin et al. 2011), Alzheimer's disease (Van der Auwera et al. 2005), or Parkinson`s disease (Hartman and Vining 2007).

Original suggestions for use of ketones in mitochondrial disease is derived from studies on cybrid cell lines. Here, ketone bodies in culture medium caused heteroplasmy shift towards wild-type mtDNA in KearnsSayre syndrome (Santra et al. 2004) and LHON with m.13094 T > C heteroplasmic mutation (Emperador et al. 2019). In both cases, heteroplasmy shift was connected with improvement of mitochondrial function. In vivo animal studies then demonstrated, that in healthy mice models, KD administration increased longevity and health-span (Roberts et al. 2017) and its beneficial effects were also demonstrated on models of mitochondrial dysfunction. Thus, KD improved assembly and activity of impaired complexes, normalized mitochondrial morphology and ultrastructure and normalized metabolomic profile in deletor mice (Ahola-Erkkilä et al. 2010) as well as in Bcs $1 l \mathrm{KO}$ model (Purhonen et al. 
2017). KD also increased mitochondrial biogenesis in brain of mice with mutated mtDNA repair enzyme UNG1 (Hasan-Olive et al. 2019). However, as a cautionary note, despite increased biogenesis, KD in this model ultimately led to aggravated neurodegeneration and mitochondrial deterioration (Lauritzen et al. 2016).

Since ketone bodies are metabolized to acetyl-CoA, they may at least partially bypass complex I, which led to a suggestion, that patients with complex I defects may benefit most from KD. Indeed, there are numerous case reports (reviewed e.g. in Scholl-Bürgi et al. 2015), which demonstrated improvement in clinical symptoms (typically seizures) but without a long-term follow-up. Utility of KD for other types of mitochondrial disease remains to be elucidated. Of interest is a study on patients with mitochondrial myopathies treated with modified Atkins diet, which led to muscle pain and selective lysis of abnormal muscle fibers, ultimately causing premature termination of that trial. However, two years of follow-up demonstrated improvement of muscle strength, suggesting activation of muscle regeneration (Ahola et al. 2016). While KD may show substantial promise in preclinical models, its use in human setting has therefore to be closely evaluated.

\section{Hypoxia}

Rather unexpected therapeutic option for mitochondrial diseases is also chronic hypoxia. Beneficial effects of chronic continuous normobaric hypoxia with $11 \%$ of oxygen were observed for mice with $N d u f_{s} 4$ knockout as well as frataxin $(F x n)$ knockdown. For $N d u f_{S} 4^{-/}$mice, hypoxia corrected biochemical defect as well as neurological phenotype and led to dramatic increase in overall survival (Ferrari et al. 2017, Jain et al. 2016). To the contrast, in frataxin shFXN model it alleviated ataxia phenotype, but without concomitant effect on survival (Ast et al. 2019). Importantly, in both cases mild hyperoxia aggravated neurological phenotype. Molecular basis for beneficial effect of hypoxia still has to be elaborated, but it was demonstrated, that in $N d u f_{S} 4^{-/-}$ mice, it is independent form the action of HIF signalling pathway. Rather, it seems that hyperoxia in the brain of $N d u f s 4^{-/}$animals is actually responsible for the development of pathology (Jain et al. 2019). Yet another physiological rationale for beneficial effect of hypoxia offers the observation on the same $N d u f_{s} 4^{-/-}$mice, that they have impaired ability to induce hypoxic pulmonary vasoconstriction (HPV) response, which matches perfusion to ventilation in lungs. However, HPV response was restored after three weeks under normobaric hypoxia. Thus, under hypoxic conditions $N d u f_{S} 4^{-/-}$mice can better regulate their blood oxygenation (Schleifer et al. 2019).

Overall, the whole phenomenon of therapeutic use of hypoxia for mitochondrial diseases is rather obscure and its utility for the whole spectrum of disease genes cannot be granted. An interesting recent study on cellular model looked for the selective essentiality of individual genes under hypoxia and hyperoxia. It identified that hypoxia can buffer the loss of most complex I genes, genes from FeS cluster biosynthesis, CoQ biosynthesis and from pyruvate dehydrogenase complex (Jain et al. 2020). It can be anticipated, that patients with mutations in genes from these pathways may benefit from hypoxia treatment, while it can be neutral or even damaging for others. All in all, while hypoxia may represent an elegant treatment option, at the moment it is still limited to preclinical evidence and no human studies have been reported, yet.

\section{Organ transplantation}

Rather niche invasive approach to treatment of mitochondrial disease is represented by organ transplants. This strategy is also utilized for other inborn errors of metabolism and can serve well in conditions, where enzyme dysfunction leads to accumulation of toxic compound, which can be cleared by the allogenic transplanted organ (Tan et al. 2019). Best example is mitochondrial neurogastrointestinal encephalomyopathy (MNGIE), caused by mutations in thymidine phosphorylase (TYMP). This leads to an accumulation of thymidine and deoxyuridine and secondary mtDNA depletion. Haematopoietic stem cell transplantation (HSCT) has been attempted in sizeable cohort of MNGIE patients and led to an improvement of both biochemical parameters and clinical symptoms (Halter et al. 2015). Rather high mortality associated with HSCT in MNGIE patients led to exploration of other strategy, namely liver transplantation, since liver has high expression of thymidine phosphorylase. Three reports to date cover six cases and all presented with improvements in biochemical and clinical characteristics at one-year follow-up (Madhok et al. 2019, D'Angelo et al. 2017, De Giorgio et al. 2016, Kripps et al. 2020).

Liver transplantation has also been attempted in patients with ethylmalonic encephalopathy caused by mutations in ETHE1 gene coding for mitochondrial sulphur dioxygenase. It is associated with toxic 
accumulation of hydrogen sulphide which inhibits cytochrome $c$ oxidase (CIV) and leads to a progressive neurological disorder (Tiranti et al. 2009). In all three cases reported so far, liver transplant led to improvement in neurological phenotype (Dionisi-Vici et al. 2016, Tam et al. 2019), but in one case this was not corroborated by improved biochemical characteristics, suggesting continued risk for the patient (Tam et al. 2019).

Overall, tissue transplants seem to be a perspective approach, effectively serving as an enzyme replacement therapy. With increasing confidence in their outcome, they can be considered for mitochondrial patients. Still, better outcomes can be expected if they are performed at early disease stage, before profound target tissue damage by toxic metabolites takes place.

\section{Genomic approach}

\section{Genome editing}

Unlike the above-mentioned types of treatment, genome editing techniques might solve the actual cause of the mitochondrial disorders and prevent a transmission to the offspring. There are several approaches, tailored for different types of disorders: (1) gene replacement, which is effective in monogenic disorders; (2) gene addition which may help in complex disorders such as heart failure and cancer; (3) gene expression alteration by RNA interference resulting in a removal of a target malfunctioning RNA; (4) precision genome editing via zinc finger endonucleases (ZFNs), TALENs (transcription activator-like effectors nucleases), or CRISPR (clustered regularly interspaced palindromic repeat)/Cas9 systems (Baker, 2012, Hsu et al. 2014, Wang and Gao, 2014). Gene editing approaches for mitochondrial diseases of nuclear origin can follow strategies for any other genetic disorder. Thus, the CRISPR/Cas9 editing system was reported in a model of CoQ deficiency, where it successfully corrected a mutation in the COQ4 (Romero-Moya et al. 2017). In contrast, mtDNA mutations require unorthodox approaches, driven by complexities of mtDNA genetics, as well as accessibility of mtDNA for genetic tools. These aspects will be discussed below.

In the case of mitochondrial disorders, LHON syndrome is a promising target of a gene therapy (Karaarslan 2019). Currently, LHON is one of the most common inherited optic neuropathies, occurring in 1 out of 30000 patients, predominantly diagnosed in young men (Yu-Wai-Man et al. 2003). As mentioned already in the Idebenone section, only $3 \mathrm{mtDNA}$ point mutations are responsible for $95 \%$ of LHON cases (Yu-Wai-Man et al. 2002). Therefore, a gene therapy approach is being investigated in ongoing clinical trials, currently in phase III. Patients with the most common mutation m.11778G $>$ A $(\sim 70 \%)$ are injected into the vitreous cavity of a single eye with a wild type ND4 protein carried by an adeno-associated viral (AAV) delivery (El-Hattab et al. 2017). ND4 transgene is modified to a nuclear DNA sequence to ensure consistency with nuclear translation and carries a mitochondrial targeting sequence (COX10 or ATP5MC1) to be transported into mitochondria after the expression in cytosol (Yang et al. 2016, Feuer et al. 2016). As reported in the clinical trials, patients' visual acuity improved and visual field was enlarged without observation of any undesirable sideeffects (Wan et al. 2016, GenSight, 2019, Yang et al. 2016, Bouquet et al. 2019, Feuer et al. 2016). Rather surprisingly, improved visual function was observed also for the second, sham treated eye, counter to natural history of the disease. Recent data from non-human primates, demonstrating presence of AAV vector also in the non-treated eye may offer a clue for this observation (Moster et al. 2020).

Since there are many copies of mtDNA per cell, only a portion of them can carry pathological variant an effect known as heteroplasmy (Gorman et al. 2016). Furthermore, levels of heteroplasmy may differ between individual cells and tissues in the body. If the percentage of heteroplasmy surpasses a certain level, called a threshold, a mitochondrial disorder can manifest. For some common mitochondrial diseases, the threshold level is known. Typically, a high proportion of mutated mtDNA ( $>60 \%$ ), including e.g. mtDNA deletions, is a prerequisite of cellular defects (Koene and Smeitink, 2011, Grady et al. 2014, Nuskova et al. 2020, Hejzlarová et al. 2015). Therefore, the various clinical presentations of mutations in mitochondrial DNA manifest as a direct consequence of the heteroplasmy level in the specific tissue (Stewart and Chinnery 2015).

Genome editing systems are being developed to manipulate levels of mtDNA heteroplasmy. Briefly, the mutated mtDNA is targeted for removal, and is hence kept under the threshold level. Several of the currently available genome editing tools had been manipulated to target into mitochondria and partially or completely remove the mutant mtDNA. These tools can also be used to reduce the levels of mutant mtDNA in embryos during in vitro fertilization (Pereira and Moraes 2017). Still, the 
current limitation of all of these approaches for clinical usage lays in the theoretical danger of rapid depletion of mtDNA (Hirano et al. 2018).

First of all, mitochondria-targeted restriction endonucleases (RE) have been tested in human-derived cell lines as well as in mouse models. RE are small enzymes able to recognize a unique DNA sequence and create double strand-breaks that lead to a rapid mtDNA removal (Bayona-Bafaluy et al. 2005). The specificity of the enzymes targets the mutated sequence and leaves the wild-type intact. However, the drawback of this approach lays in the finite number of available RE. Effectively, the only example of RE targeting human pathogenic mutation is SmaI and its isoschisomer XmaI, which cleave m.8993T $>$ G mutation in MT-ATP6 causing severe earlyonset NARP (neuropathy, ataxia, and retinitis pigmentosa) or MILS (maternally inherited Leigh syndrome) syndrome. The usage of this RE resulted in an increased ATP production in cybrid cells (Tanaka et al. 2002, Alexeyev et al. 2008). Mouse studies demonstrated in vivo utility of RE approach on polymorphisms between NZB and BALB mtDNA. Here, ApaLI and Scal RE were delivered via viral vectors and both lead to a significant shift in mtDNA heteroplasmy in either muscle and brain, or liver tissue (Bayona-Bafaluy et al. 2005, Bacman et al. 2007)

Next, ZFNs and TALENs have been manipulated for mitochondrial localization. In contrast to RE, ZFNs and TALENs can be designed to target a specific sequence. First mitochondrially targeted ZFNs aimed pathogenic mtDNA with $\mathrm{m} .8993 \mathrm{~T}>\mathrm{G}$ point mutation mentioned above and a large "common deletion" (a 4977-bp deletion causing CPEO, KearnsSayre or Pearson's marrow pancreas syndromes). This study successfully decreased mutant mtDNA haplotype load without mtDNA depletion and with restoration of OXPHOS function in a cybrid cell model (Gammage et al. 2014). Next, mtZFN were used in mouse m.5024C $>\mathrm{T}$ tRNA $^{\text {Ala }}$ model, where mtZFNs delivered by AAV eliminated mutant mtDNA and reversed molecular and biochemical phenotypes in heart (Gammage et al. 2018b). Another study demonstrated possible utility of mtZFNs in early mouse embryos to prevent transmission of mutated mtDNA through the germline (McCann et al. 2018).

Similarly, mitochondrial targeted TALENs (mitoTALENs) were tested in several patient-derived cell models of mtDNA mutation. MitoTALENs activity led to a reduction of mutated mtDNA (Bacman et al. 2013). In the next study, mitoTALENs were designed to target frequent point mutations m.8344A $>\mathrm{G}$ (causing MERRF myoclonic epilepsy with ragged red fibers) and m.13513G $>$ A (causing MELAS/Leigh syndrome). Both mitoTALENs were able to manipulate heteroplasmy and improve OXPHOS capacity. Also, TALENs targeting m. $8344 \mathrm{~A}>\mathrm{G}$ were reduced in size for a better viral packaging with aim to increase its therapeutic potential (Hashimoto et al. 2015, Pereira et al. 2018). In vivo utility was demonstrated in mouse m.5024C $>\mathrm{T}$ tRNA ${ }^{\text {Ala }}$ model, where AAV delivered mitoTALENs stably reduced load of mutant mtDNA in the affected tissues, muscle and heart, and this was accompanied by concurrent restoration of tRNA ${ }^{\text {Ala }}$ levels (Bacman et al. 2018).

Most controversial at the moment is the possibility to adapt CRISPR based systems for mtDNA editing. Gammage et al. (2018a) claim that usage of CRISPR/Cas9 to manipulate mtDNA is questionable because of theoretical impossibility to transport so called guide RNA (gRNA) to mitochondria. CRISPR/Cas9 system is however dependent on the presence of gRNA, because it recognizes the targeted binding site. Still, mitochondrially targeted Cas9 (mitoCas9) was reported to specifically cleave mtDNA. Presumably, the mitoCas9 is able to bind the gRNA in the cytoplasm and transport it into the mitochondria (Jo et al. 2015). Moreover, the CRISPR/Cas9 system was able to edit mtDNA by knockin strategy both in human cells and zebrafish. $\mathrm{F}_{1}$ zebrafish offspring were found to harbour the designed mtDNA mutation (Bian et al. 2019). The newest development in the mitochondrial CRISPR system operates with stem loop element added to the gRNA that facilitates its transport into the organelle (Hussain et al. 2020).

Altogether, all gene editing techniques may present a potential individual-based therapy for the treatment of inherited mitochondrial diseases in the future.

\section{Mitochondrial replacement therapy}

Mitochondrial replacement therapy (MRT) presents relatively novel and effective technique in avoidance of inheritance of mtDNA mutations. If a mother is at risk of transmitting mutated mtDNA to her offspring, she can take the advantage of mitochondrial donation techniques. Either a maternal spindle transfer or pronuclear transfer is used, differing in the timing of the transfer, whether it is performed pre- or post-fertilization. In principle, the nuclear material (i.e. spindle or pronuclei) is removed from a mother's oocyte and 
transferred into a donor denucleated oocyte, where the healthy mitochondria are already located in cytoplasm (Rai et al. 2018). However, there is always a risk of the disease development, since a small amount of mutated mtDNAs are transferred from the recipient mother's mitochondria during the process. Unfortunately, if more than $5 \%$ of the mutant mtDNA is transmitted, a significant chance of disease development exists (Samuels et al. 2013). The preclinical studies and optimization were able to lower the mutant molecules to less than $2 \%$ (Hyslop et al. 2016). Thus, MRT techniques were successfully used in a mother carrying m.8993T $>$ G mutation causing Leigh syndrome with a history of unsuccessful pregnancies. Her son born from MRT carried mutation load of 2.36-9.23\% in tested tissues and was 7 months old at the time of publication. Long-term follow up is crucial (Zhang et al. 2017).

Another concern lays in the incompatibility of the nuclear and mitochondrial genomes. Concurrently, the outcome of a genome incompatibility in the case of introducing a novel mtDNA to a foreign nuclear genome is still questionable. Therefore, donor mothers with matching haplotype should be selected (Pan et al. 2019, Gómez-Tatay et al. 2017).

MRT usually undergoes thorough ethical reviews in countries considering its legalization. This process had been very transparent in the United Kingdom, where MRT was finally permitted in 2015 (Lightowlers et al. 2015, Gorman et al. 2016). Later, in 2017, the first clinic in the UK was licensed to provide this treatment (Rahman and Rahman 2018). A current clinical trial will assess the outcome of mitochondrial donation on the first 75 children born (Russell et al. 2020). Ethical issues are still a matter of concern and for example in the USA, a National Academies of Sciences expert committee recommends to create male offspring to reduce the risk of disease transmission to the next generations (Reardon 2016). Despite this, during the end of 2019, USA has taken a fairly restrictive approach to MRTs (Cohen et al. 2020). Specifically, in the Czech Republic, the legislature does not regulate the mitochondrial transfer, however, the potential usage of MRT must be approved by the State Institute for Drug Control.

In general, legal approach towards MRT is still developing. In addition to the United Kingdom, the Governments of Australia and Singapore are in the process of formal discussions aimed at MRT legalisation, but no formal decisions have been reached yet. Situation in other countries is even hazier. A recent study identified 21 countries where cytoplasmic transfer or nuclear transfer was available, namely Albania, Barbados, France, Georgia, Germany, Greece, India, Israel, Mexico, Northern Cyprus, Panama, Philippines, Portugal, Russian Federation, Serbia, Singapore, South Africa, Spain, Thailand, Turkey and Ukraine (Ishii and Hibino 2018). Clinical trial registries and the websites of clinics offering cross-border reproductive care were then identified in 16 countries: Albania, Canada, Czech Republic, China, India, Israel, Italy, Japan, Mexico, Northern Cyprus, Spain, Taiwan, Turkey, Ukraine, UAE and USA (Ishii and Hibino 2018). On the other hand, other prerequisites for MRT, such as oocyte donation are not permitted in some of the listed countries (e.g. Germany, Turkey, UAE), which effectively prevents MRT in those countries. Because of restrictions in some countries and permissions in others, reproductive cross-border traveling is expected. In forthcoming laws, to prevent inheritance of modified genetic information, male-only selection of embryos for implantation could be preferable, but this raises ethical and moral issues.

\section{Concluding remarks}

Diagnosis of mitochondrial disorders has been accelerated by introducing Next-Generation Sequencing techniques in recent years. However, the treatment options are still very limited and for many patients only supportive or symptomatic therapies are available (Hirano et al. 2018). As discussed, most of the available therapies are in the phase of ongoing clinical trials and therefore still considered as an experimental treatment.

The potential for future development lays in discovery of new therapeutic options. The phenotypic and genotypic range of mitochondrial disorders (Fig. 1) complicates therapeutic approaches. Evidently, the final decision for a specific treatment must reflect the cause of the disease. Principally, rare mitochondrial disorders demand 'rare' treatment tactics, hence personalized medicine. First of all, the metabolic approach could be favorable for some patients - endurance training for patients with mutations and deletions in mtDNA and ketogenic diet for patients with complex I deficiency. Luckily, drug development is a rapidly evolving field and many drugs currently undergoing approval process are in different phases of clinical trials. Yet, only 10 out of 49 clinical trials focusing on mitochondrial disease are currently in Phase III (Weissig 2020). In principle, only 
Idebenone has been approved by U.S. Food and Drug Administration and European Medicines Agency specifically for treatment of mitochondrial disorders.

It is unlikely that there will be a drug to address a broad range of mitochondrial disorders. Yet, some underlaying biochemical principles or disease outcomes (such as accelerated glycolysis, increased ROS production, lack of a specific vitamin/cofactor) may be similar, revealing potential selective therapeutic directions as well. One promising example is represented by a current study of an engineered enzyme LOXCAT. It is able to extracellularly convert lactate and oxygen to pyruvate and water in order to manipulate lactate/pyruvate proportion and hence intracellular $\mathrm{NADH} / \mathrm{NAD}^{+}$ratio. Since patient cells and tissues often show shift in NADH/NAD ${ }^{+}$balance, which is subsequently responsible for a 'reductive stress', correction of this disbalance may be therapeutically effective. LOXCAT technique has been submitted for a patent consideration (Patgiri et al. 2020).

Moreover, mitochondrial deficiency can also be a secondary defect in common diseases such as Parkinson's, Alzheimer's, ALS or cancer (Hadrava Vanova et al. 2020, Cedikova et al. 2016). These conditions may drive the necessary research associated with drug development and allow later repurposing for primary mitochondrial diseases. Together with novel approaches including gene therapy or mitochondrial donation, potential cure is becoming available for an increasing number of patients. It is therefore important to recognize patients that could profit from any supplementation, such as vitamins or antioxidants, as early as possible, in order to maximize treatment benefits (Distelmaier et al. 2017).

Also, the change of attitude towards clinical trials will be required in the future, especially in the case of mitochondrial diseases. It is hardly acceptable to deny treatment to the patient in cases, where a functioning therapy exists, even if it is still considered as experimental. Good example here is nucleoside bypass therapy in $T K 2$ deficiency, where a successful treatment outcome can only be evaluated against natural disease progression and placebo-controlled trial will now hardly be approved. Therefore, the history of a successful compassionate use should be a sufficient proof for a drug approval. Altogether, the rare diseases require an innovative trial design (Abrahamyan et al. 2016, Rahman and Rahman, 2018). Simultaneously, due to clinical heterogeneity and limited number of patients manifesting the same phenotype, it is crucial to establish international consortia in order to find a treatment.

The future of personalized medicine lays in further adoption of gene therapy and mitochondrial replacement techniques despite all ethical controversies. Especially the MRT offers a possibility of having children for women with mtDNA mutation. Often, these women suffered from miscarriages and were forced to voluntary childlessness, oocyte donation or adoption. However, genetic counselling and preimplantation genetic diagnosis still represents option for parents with a child carrying any type of mutation to mitigate the chances of having another child affected by the same disorder.

\section{Conflict of Interest}

There is no conflict of interest.

\section{Acknowledgements}

This work was supported by Czech Health Research Council (NV19-07-00149). Institutional support (Institute of Physiology) was provided by Czech Academy of Sciences (RVO:67985823). We acknowledge Kristýna Čunátová for her assistance in preparation of Figure 1.

\section{References}

ABDELMALAK M, LEW A, RAMEZANI R, SHROADS AL, COATS BS, LANGAEE T, SHANKAR MN, NEIBERGER RE, SUBRAMONY SH, STACPOOLE PW: Long-term safety of dichloroacetate in congenital lactic acidosis. Mol Genet Metab 109: 139-143, 2013. https://doi.org/10.1016/j.ymgme.2013.03.019

ABRAHAMYAN L, FELDMAN BM, TOMLINSON G, FAUGHNAN ME, JOHNSON SR, DIAMOND IR, GUPTA S: Alternative designs for clinical trials in rare diseases. Am J Med Genet C Semin Med Genet 172: 313-331, 2016. https://doi.org/10.1002/ajmg.c.31533

ACOSTA MJ, VAZQUEZ FONSECA L, DESBATS MA, CERQUA C, ZORDAN R, TREVISSON E, SALVIATI L: Coenzyme Q biosynthesis in health and disease. Biochim Biophys Acta 1857: 1079-1085, 2016. https://doi.org/10.1016/j.bbabio.2016.03.036 
AHOLA-ERKKILÄ S, CARROLL CJ, PELTOLA-MJÖSUND K, TULKKI V, MATTILA I, SEPPÄNEN-LAAKSO T, ORESIC M, TYYNISMAA H, SUOMALAINEN A: Ketogenic diet slows down mitochondrial myopathy progression in mice. Hum Mol Genet 19: 1974-1984, 2010. https://doi.org/10.1093/hmg/ddq076

AHOLA S, AURANEN M, ISOHANNI P, NIEMISALO S, URHO N, BUZKOVA J, VELAGAPUDI V, LUNDBOM N, HAKKARAINEN A, MUURINEN T, PIIRILÄ P, PIETILÄINEN KH, SUOMALAINEN A: Modified Atkins diet induces subacute selective ragged-red-fiber lysis in mitochondrial myopathy patients. EMBO Mol Med 8: 1234-1247, 2016. https://doi.org/10.15252/emmm.201606592

ALEXEYEV MF, VENEDIKTOVA N, PASTUKH V, SHOKOLENKO I, BONILLA G, WILSON GL: Selective elimination of mutant mitochondrial genomes as therapeutic strategy for the treatment of NARP and MILS syndromes. Gene Ther 15: 516-523, 2008. https://doi.org/10.1038/gt.2008.11

AST T, MEISEL JD, PATRA S, WANG H, GRANGE RMH, KIM SH, CALVO SE, OREFICE LL, NAGASHIMA F, ICHINOSE F, ZAPOL WM, RUVKUN G, BARONDEAU DP, MOOTHA VK: Hypoxia rescues frataxin loss by restoring iron sulfur cluster biogenesis. Cell 177: 1507-1521 e1516, 2019. https://doi.org/10.1016/j.cell.2019.03.045

AWAD AM, BRADLEY MC, FERNÁNDEZ-DEL-RÍO L, NAG A, TSUI HS, CLARKE CF: Coenzyme Q(10) deficiencies: pathways in yeast and humans. Essays Biochem 62: 361-376, 2018. https://doi.org/10.1042/EBC20170106

BACMAN SR, KAUPPILA JHK, PEREIRA CV, NISSANKA N, MIRANDA M, PINTO M, WILLIAMS SL, LARSSON NG, STEWART JB, MORAES CT: MitoTALEN reduces mutant mtDNA load and restores tRNA(Ala) levels in a mouse model of heteroplasmic mtDNA mutation. Nat Med 24: 1696-1700, 2018. https://doi.org/10.1038/s41591-018-0166-8

BACMAN SR, WILLIAMS SL, HERNANDEZ D, MORAES CT: Modulating mtDNA heteroplasmy by mitochondriatargeted restriction endonucleases in a 'differential multiple cleavage-site' model. Gene Ther 14: 1309-1318, 2007. https://doi.org/10.1038/sj.gt.3302981

BACMAN SR, WILLIAMS SL, PINTO M, PERALTA S, MORAES CT: Specific elimination of mutant mitochondrial genomes in patient-derived cells by mitoTALENs. Nat Med 19: 1111-1113, 2013. https://doi.org/10.1038/nm.3261

BAKER M: Gene-editing nucleases. Nat Methods 9: 23-26, 2012. https://doi.org/10.1038/nmeth.1807

BALASUBRAMANIAM S, CHRISTODOULOU J, RAHMAN S: Disorders of riboflavin metabolism. J Inherit Metab Dis 42: 608-619, 2019. https://doi.org/10.1002/jimd.12058

BARSHOP BA, NAVIAUX RK, MCGOWAN KA, LEVINE F, NYHAN WL, LOUPIS-GELLER A, HAAS RH: Chronic treatment of mitochondrial disease patients with dichloroacetate. Mol Genet Metab 83: 138-149, 2004. https://doi.org/10.1016/j.ymgme.2004.06.009

BATES MG, NEWMAN JH, JAKOVLJEVIC DG, HOLLINGSWORTH KG, ALSTON CL, ZALEWSKI P, KLAWE JJ, BLAMIRE AM, MACGOWAN GA, KEAVNEY BD, BOURKE JP, SCHAEFER A, MCFARLAND R, NEWTON JL, TURNBULL DM, TAYLOR RW, TRENELL MI, GORMAN GS: Defining cardiac adaptations and safety of endurance training in patients with m.3243A $>$ G-related mitochondrial disease. Int J Cardiol 168: 3599-3608, 2013. https://doi.org/10.1016/j.ijcard.2013.05.062

BAYONA-BAFALUY MP, BLITS B, BATTERSBY BJ, SHOUBRIDGE EA, MORAES CT: Rapid directional shift of mitochondrial DNA heteroplasmy in animal tissues by a mitochondrially targeted restriction endonuclease. Proc Natl Acad Sci U S A 102: 14392-14397, 2005. https://doi.org/10.1073/pnas.0502896102

BELENKY P, BOGAN KL, BRENNER C: NAD ${ }^{+}$metabolism in health and disease. Trends Biochem Sci 32: 12-19, 2007. https://doi.org/10.1016/j.tibs.2006.11.006

BÉNIT P, GONCALVES S, DASSA EP, BRIÈRE JJ, RUSTIN P: The variability of the harlequin mouse phenotype resembles that of human mitochondrial-complex I-deficiency syndromes. PLoS One 3: e3208, 2008. https://doi.org/10.1371/journal.pone.0003208

BIAN WP, CHEN YL, LUO JJ, WANG C, XIE SL, PEI DS: Knock-in strategy for editing human and zebrafish mitochondrial DNA using Mito-CRISPR/Cas9 system. ACS Synth Biol 8: 621-632, 2019. https://doi.org/10.1021/acssynbio.8b00411 
BILLINGTON RA, BRUZZONE S, DE FLORA A, GENAZZANI AA, KOCH-NOLTE F, ZIEGLER M, ZOCCHI E: Emerging functions of extracellular pyridine nucleotides. Mol Med 12: 324-327, 2006. https://doi.org/10.2119/2006-00075.Billington

BLÁZQUEZ-BERMEJO C, MOLINA-GRANADA D, VILA-JULIÀ F, JIMÉNEZ-HEIS D, ZHOU X, TORRESTORRONTERAS J, KARLSSON A, MARTÍ R, CÁMARA Y: Age-related metabolic changes limit efficacy of deoxynucleoside-based therapy in thymidine kinase 2-deficient mice. EBioMedicine 46: 342-355, 2019. https://doi.org/10.1016/j.ebiom.2019.07.042

BONNEFONT JP, BASTIN J, LAFORÊT P, AUBEY F, MOGENET A, ROMANO S, RICQUIER D, GOBINLIMBALLE S, VASSAULT A, BEHIN A, EYMARD B, BRESSON JL, DJOUADI F: Long-term follow-up of bezafibrate treatment in patients with the myopathic form of carnitine palmitoyltransferase 2 deficiency. Clin Pharmacol Ther 88: 101-108, 2010. https://doi.org/10.1038/clpt.2010.55

BOUQUET C, VIGNAL CLERMONT C, GALY A, FITOUSSI S, BLOUIN L, MUNK MR, VALERO S, MEUNIER S, KATZ B, SAHEL JA, THOMASSON N: Immune response and intraocular inflammation in patients with leber hereditary optic neuropathy treated with intravitreal injection of recombinant adeno-associated virus 2 carrying the ND4 gene: a secondary analysis of a phase 1/2 clinical trial. Jama Ophthalmol 137: 399-406, 2019. https://doi.org/10.1001/jamaophthalmol.2018.6902

BUYSE G, MERTENS L, DI SALVO G, MATTHIJS I, WEIDEMANN F, EYSKENS B, GOOSSENS W, GOEMANS N, SUTHERLAND GR, VAN HOVE JL: Idebenone treatment in Friedreich's ataxia: neurological, cardiac, and $\begin{array}{lllll}\text { biochemical } & \text { monitoring. } & \text { Neurology } & 6003 .\end{array}$ https://doi.org/10.1212/01.WNL.0000068549.52812.0F

CAGLAYAN AO, GUMUS H, SANDFORD E, KUBISIAK TL, MA Q, OZEL AB, PER H, LI JZ, SHAKKOTTAI VG, BURMEISTER M: COQ4 mutation leads to childhood-onset ataxia improved by CoQ10 administration. Cerebellum 18: 665-669, 2019. https://doi.org/10.1007/s12311-019-01011-x

CEDIKOVA M, PITULE P, KRIPNEROVA M, MARKOVA M, KUNCOVA J: Multiple roles of mitochondria in aging processes. Physiol Res 65: S519-S531, 2016. https://doi.org/10.33549/physiolres.933538

CERUTTI R, PIRINEN E, LAMPERTI C, MARCHET S, SAUVE AA, LI W, LEONI V, SCHON EA, DANTZER F, AUWERX J, VISCOMI C, ZEVIANI M: NAD(+)-dependent activation of Sirt1 corrects the phenotype in a mouse model of mitochondrial disease. Cell Metab 19: 1042-1049, 2014. https://doi.org/10.1016/j.cmet.2014.04.001

CIVILETTO G, DOGAN SA, CERUTTI R, FAGIOLARI G, MOGGIO M, LAMPERTI C, BENINCÁ C, VISCOMI C, ZEVIANI M: Rapamycin rescues mitochondrial myopathy via coordinated activation of autophagy and lysosomal biogenesis. EMBO Mol Med 10: 2018. https://doi.org/10.15252/emmm.201708799

CLARK-MATOTT J, SALEEM A, DAI Y, SHURUBOR Y, MA X, SAFDAR A, BEAL MF, TARNOPOLSKY M, SIMON DK: Metabolomic analysis of exercise effects in the POLG mitochondrial DNA mutator mouse brain. Neurobiol Aging 36: 2972-2983, 2015. https://doi.org/10.1016/j.neurobiolaging.2015.07.020

COHEN IG, ADASHI EY, GERKE S, PALACIOS-GONZÁLEZ C, RAVITSKY V: The regulation of mitochondrial replacement techniques around the world. Annu Rev Genomics Hum Genet 2020. https://doi.org/10.1146/annurev-genom-111119-101815

D'ANGELO R, RINALDI R, PIRONI L, DOTTI MT, PINNA AD, BOSCHETTI E, CAPRISTO M, MOHAMED S, CONTIN M, CAPORALI L, CARELLI V, DE GIORGIO R: Liver transplant reverses biochemical imbalance in mitochondrial neurogastrointestinal encephalomyopathy. Mitochondrion 34: 101-102, 2017. https://doi.org/10.1016/j.mito.2017.02.006

DAI Y, ZHENG K, CLARK J, SWERDLOW RH, PULST SM, SUTTON JP, SHINOBU LA, SIMON DK: Rapamycin drives selection against a pathogenic heteroplasmic mitochondrial DNA mutation. Hum Mol Genet 23: 637-647, 2014. https://doi.org/10.1093/hmg/ddt450

DE GIORGIO R, PIRONI L, RINALDI R, BOSCHETTI E, CAPORALI L, CAPRISTO M, CASALI C, CENACCHI G, CONTIN M, D'ANGELO R, D'ERRICO A, GRAMEGNA LL, LODI R, MARESCA A, MOHAMED S, MORELLI MC, PAPA V, TONON C, TUGNOLI V, CARELLI V, D'ALESSANDRO R, PINNA AD: Liver transplantation for mitochondrial neurogastrointestinal encephalomyopathy. Ann Neurol 80: 448-455, 2016. https://doi.org/10.1002/ana.24724 
DE HAAS R, DAS D, GARANTO A, RENKEMA HG, GREUPINK R, VAN DEN BROEK P, PERTIJS J, COLLIN RWJ, WILLEMS P, BEYRATH J, HEERSCHAP A, RUSSEL FG, SMEITINK JA: Therapeutic effects of the mitochondrial ROS-redox modulator KH176 in a mammalian model of Leigh Disease. Sci Rep 7: 11733, 2017. https://doi.org/10.1038/s41598-017-09417-5

DI PROSPERO NA, BAKER A, JEFFRIES N, FISCHBECK KH: Neurological effects of high-dose idebenone in patients with Friedreich's ataxia: a randomised, placebo-controlled trial. Lancet Neurol 6: 878-886, 2007. https://doi.org/10.1016/S1474-4422(07)70220-X

DILLON LM, HIDA A, GARCIA S, PROLLA TA, MORAES CT: Long-term bezafibrate treatment improves skin and spleen phenotypes of the mtDNA mutator mouse. PLoS One 7: e44335, 2012. https://doi.org/10.1371/journal.pone.0044335

DIONISI-VICI C, DIODATO D, TORRE G, PICCA S, PARIANTE R, GIUSEPPE PICARDO S, DI MEO I, RIZZO C, TIRANTI V, ZEVIANI M, DE VILLE DE GOYET J: Liver transplant in ethylmalonic encephalopathy: a new treatment for an otherwise fatal disease. Brain 139: 1045-1051, 2016. https://doi.org/10.1093/brain/aww013

DISTELMAIER F, HAACK TB, WORTMANN SB, MAYR JA, PROKISCH H: Treatable mitochondrial diseases: cofactor metabolism and beyond. Brain 140: e11, 2017. https://doi.org/10.1093/brain/aww303

DOMÍNGUEZ-GONZÁLEZ C, MADRUGA-GARRIDO M, MAVILLARD F, GARONE C, AGUIRRERODRÍGUEZ FJ, DONATI MA, KLEINSTEUBER K, MARTÍ I, MARTÍN-HERNÁNDEZ E, MOREALEJO-AYCINENA JP, MUNELL F, NASCIMENTO A, KALKO SG, SARDINA MD, ÁLVAREZ DEL VAYO C, SERRANO O, LONG Y, TU Y, LEVIN B, THOMPSON JLP, ENGELSTAD K, UDDIN J, TORRES-TORRONTERAS J, JIMENEZ-MALLEBRERA C, MARTÍ R, PARADAS C, HIRANO M: Deoxynucleoside therapy for thymidine kinase 2-deficient myopathy. Ann Neurol 86: 293-303, 2019. https://doi.org/10.1002/ana.25506

DOUIEV L, SHEFFER R, HORVATH G, SAADA A: Bezafibrate improves mitochondrial fission and function in DNM1L-deficient patient cells. Cells 9: 2020. https://doi.org/10.3390/cells9020301

EHINGER JK, PIEL S, FORD R, KARLSSON M, SJÖVALL F, FROSTNER E, MOROTA S, TAYLOR RW, TURNBULl DM, CORNELL C, MOSS SJ, METZSCH C, HANSSON MJ, FLIRI H, ELMÉR E: Cell-permeable succinate prodrugs bypass mitochondrial complex I deficiency. Nat Commun 7: 12317, 2016. https://doi.org/10.1038/ncomms12317

EL-HATTAB AW, ZARANTE AM, ALMANNAI M, SCAGLIA F: Therapies for mitochondrial diseases and current clinical trials. Mol Genet Metab 122: 1-9, 2017. https://doi.org/10.1016/j.ymgme.2017.09.009

EMA: European Medicines Agency: CHMP ASSESSMENT REPORT FOR Sovrima. 2008.

EMPERADOR S, LÓPEZ-GALLARDO E, HERNÁNDEZ-AINSA C, HABBANE M, MONTOYA J, BAYONABAFALUY MP, RUIZ-PESINI E: Ketogenic treatment reduces the percentage of a LHON heteroplasmic mutation and increases mtDNA amount of a LHON homoplasmic mutation. Orphanet J Rare Dis 14: 150, 2019. https://doi.org/10.1186/s13023-019-1128-z

ENMC., MARTÍ R, HIRANO M: Recommendations for treatment of mitochondrial DNA maintenance disorders (232nd ENMC International Workshop). 2017.

ENNS GM: Treatment of mitochondrial disorders: antioxidants and beyond. J Child Neurol 29: 1235-1240, 2014. https://doi.org/10.1177/0883073814538509

FERRARI M, JAIN IH, GOLDBERGER O, REZOAGLI E, THOONEN R, CHENG KH, SOSNOVIK DE, SCHERRER-CROSBIE M, MOOTHA VK, ZAPOL WM: Hypoxia treatment reverses neurodegenerative disease in a mouse model of Leigh syndrome. Proc Natl Acad Sci U S A 114: E4241-e4250, 2017. https://doi.org/10.1073/pnas.1621511114

FERRIERO R, IANNUZZI C, MANCO G, BRUNETTI-PIERRI N: Differential inhibition of PDKs by phenylbutyrate and enhancement of pyruvate dehydrogenase complex activity by combination with dichloroacetate. J Inherit Metab Dis 38: 895-904, 2015. https://doi.org/10.1007/s10545-014-9808-2

FEUER WJ, SCHIFFMAN JC, DAVIS JL, PORCIATTI V, GONZALEZ P, KOILKONDA RD, YUAN H, LALWANI A, LAM BL, GUY J: Gene therapy for leber hereditary optic neuropathy: initial results. Ophthalmology 123 : 558-570, 2016. https://doi.org/10.1016/j.ophtha.2015.10.025 
FIUZA-LUCES C, DÍEZ-BERMEJO J, FERNÁNDEZ DELATM, RODRÍGUEZ-ROMO G, SANZ-AYÁN P, DELMIRO A, MUNGUÍA-IZQUIERDO D, RODRÍGUEZ-GÓMEZ I, ARA I, DOMÍNGUEZ-GONZÁLEZ C, ARENAS J, MARTÍN MA, LUCIA A, MORÁN M: Health benefits of an innovative exercise program for mitochondrial disorders. Med Sci Sports Exerc 50: 1142-1151, 2018. https://doi.org/10.1249/MSS.0000000000001546

FIUZA-LUCES C, VALENZUELA PL, LAINE-MENÉNDEZ S, FERNÁNDEZ-DE LA TORRE M, BERMEJOGÓMEZ V, RUFIÁN-VÁZQUEZ L, ARENAS J, MARTÍN MA, LUCIA A, MORÁN M: Physical exercise and mitochondrial disease: insights from a mouse model. Front Neurol 10: 790, 2019. https://doi.org/10.3389/fneur.2019.00790

FREISINGER P, HORVATH R, MACMILLAN C, PETERS J, JAKSCH M: Reversion of hypertrophic cardiomyopathy in a patient with deficiency of the mitochondrial copper binding protein Sco2: is there a potential effect of copper? J Inherit Metab Dis 27: 67-79, 2004. https://doi.org/10.1023/B:BOLI.0000016614.47380.2f

GAMMAGE PA, MORAES CT, MINCZUK M: Mitochondrial genome engineering: the revolution may not be CRISPR-Ized. Trends Genet 34: 101-110, 2018a. https://doi.org/10.1016/j.tig.2017.11.001

GAMMAGE PA, RORBACH J, VINCENT AI, REBAR EJ, MINCZUK M: Mitochondrially targeted ZFNs for selective degradation of pathogenic mitochondrial genomes bearing large-scale deletions or point mutations. EMBO Mol Med 6: 458-466, 2014. https://doi.org/10.1002/emmm.201303672

GAMMAGE PA, VISCOMI C, SIMARD ML, COSTA ASH, GAUDE E, POWELL CA, VAN HAUTE L, MCCANN BJ, REBELO-GUIOMAR P, CERUTTI R, ZHANG L, REBAR EJ, ZEVIANI M, FREZZA C, STEWART JB, MINCZUK M: Genome editing in mitochondria corrects a pathogenic mtDNA mutation in vivo. Nat Med 24: 1691-1695, 2018b. https://doi.org/10.1038/s41591-018-0165-9

GARONE C, GARCIA-DIAZ B, EMMANUELE V, LOPEZ LC, TADESSE S, AKMAN HO, TANJI K, QUINZII CM, HIRANO M: Deoxypyrimidine monophosphate bypass therapy for thymidine kinase 2 deficiency. EMBO Mol Med 6: 1016-1027, 2014. https://doi.org/10.15252/emmm.201404092

GARONE C, VISCOMI C: Towards a therapy for mitochondrial disease: an update. Biochem Soc Trans 46: 1247-1261, 2018. https://doi.org/10.1042/BST20180134

GENSIGHT B: GenSight Biologics reports findings from REALITY study and REVERSE-RESCUE analysis highlighting positive benefits from LUMEVOQ ${ }^{\mathrm{TM}}$ (GS010) compared to LHON natural history. Paris, France. 2019.

GLOVER EI, MARTIN J, MAHER A, THORNHILL RE, MORAN GR, TARNOPOLSKY MA: A randomized trial of coenzyme Q10 in mitochondrial disorders. Muscle Nerve 42: 739-748, 2010. https://doi.org/10.1002/mus.21758

GÓMEZ-TATAY L, HERNÁNDEZ-ANDREU JM, AZNAR J: Mitochondrial Modification Techniques and Ethical Issues. J Clin Med 6: 2017. https://doi.org/10.3390/jcm6030025

GORMAN GS, CHINNERY PF, DIMAURO S, HIRANO M, KOGA Y, MCFARLAND R, SUOMALAINEN A, THORBURN DR, ZEVIANI M, TURNBULL DM: Mitochondrial diseases. Nat Rev Dis Primers 2: 16080, 2016. https://doi.org/10.1038/nrdp.2016.80

GRADY JP, CAMPBELL G, RATNAIKE T, BLAKELY EL, FALKOUS G, NESBITT V, SCHAEFER AM, MCNALLY RJ, GORMAN GS, TAYLOR RW, TURNBULL DM, MCFARLAND R: Disease progression in patients with single, large-scale mitochondrial DNA deletions. Brain 137: 323-334, 2014. https://doi.org/10.1093/brain/awt321

GRAY LR, TOMPKINS SC, TAYLOR EB: Regulation of pyruvate metabolism and human disease. Cell Mol Life Sci 71: 2577-2604, 2014. https://doi.org/10.1007/s00018-013-1539-2

GUSIC M, SCHOTTMANN G, FEICHTINGER RG, DU C, SCHOLZ C, WAGNER M, MAYR JA, LEE CY, YÉPEZ VA, LORENZ N, MORALES-GONZALEZ S, PANNEMAN DM, RÖTIG A, RODENBURG RJT, WORTMANN SB, PROKISCH H, SCHUELKE M: Bi-Allelic UQCRFS1 variants are associated with mitochondrial complex III deficiency, cardiomyopathy, and alopecia totalis. Am J Hum Genet 106: 102-111, 2020. https://doi.org/10.1016/j.ajhg.2019.12.005 
HAACK TB, DANHAUSER K, HABERBERGER B, HOSER J, STRECKER V, BOEHM D, UZIEL G, LAMANTEA E, INVERNIZZI F, POULTON J, ROLINSKI B, IUSO A, BISKUP S, SCHMIDT T, MEWES HW, WITTIG I, MEITINGER T, ZEVIANI M, PROKISCH H: Exome sequencing identifies ACAD9 mutations as a cause of complex I deficiency. Nat Genet 42: 1131-1134, 2010. https://doi.org/10.1038/ng.706

HAACK TB, KLEE D, STROM TM, MAYATEPEK E, MEITINGER T, PROKISCH H, DISTELMAIER F: Infantile Leigh-like syndrome caused by SLC19A3 mutations is a treatable disease. Brain 137: e295, 2014. https://doi.org/10.1093/brain/awu128

HADRAVA VANOVA K, KRAUS M, NEUZIL J, ROHLENA J: Mitochondrial complex II and reactive oxygen species in disease and therapy. Redox Rep 25: 26-32, 2020. https://doi.org/10.1080/13510002.2020.1752002

HALLIWELL B, GUTTERIDGE JMC: Free radicals in biology and medicine, Oxford University Press, 2015. https://doi.org/10.1093/acprof:oso/9780198717478.001.0001

HALTER JP, MICHAEL W, SCHÜPBACH M, MANDEL H, CASALI C, ORCHARD K, COLLIN M, VALCARCEL D, ROVELLI A, FILOSTO M, DOTTI MT, MAROTTA G, PINTOS G, BARBA P, ACCARINO A, FERRA C, ILLA I, BEGUIN Y, BAKKER JA, BOELENS JJ, DE COO IF, FAY K, SUE CM, NACHBAUR D, ZOLLER H, SOBREIRA C, PINTO SIMOES B, HAMMANS SR, SAVAGE D, MARTÍ R, CHINNERY PF, ELHASID R, GRATWOHL A, HIRANO M: Allogeneic haematopoietic stem cell transplantation for mitochondrial neurogastrointestinal encephalomyopathy. Brain 138: 2847-2858, 2015. https://doi.org/10.1093/brain/awv226

HANDSCHIN C, SPIEGELMAN BM: Peroxisome proliferator-activated receptor gamma coactivator 1 coactivators, energy homeostasis, and metabolism. Endocr Rev 27: 728-735, 2006. https://doi.org/10.1210/er.2006-0037

HARGREAVES IP: Coenzyme Q10 as a therapy for mitochondrial disease. Int J Biochem Cell Biol 49: 105-111, 2014. https://doi.org/10.1016/j.biocel.2014.01.020

HARTMAN AL, VINING EP: Clinical aspects of the ketogenic diet. Epilepsia 48: 31-42, 2007. https://doi.org/10.1111/j.1528-1167.2007.00914.x

HASAN-OLIVE MM, LAURITZEN KH, ALI M, RASMUSSEN LJ, STORM-MATHISEN J, BERGERSEN LH: A ketogenic diet improves mitochondrial biogenesis and bioenergetics via the PGC1 $\alpha-S I R T 3-U C P 2$ axis. Neurochem Res 44: 22-37, 2019. https://doi.org/10.1007/s11064-018-2588-6

HASHIMOTO M, BACMAN SR, PERALTA S, FALK MJ, CHOMYN A, CHAN DC, WILLIAMS SL, MORAES CT: MitoTALEN: A general approach to reduce mutant mtDNA loads and restore oxidative phosphorylation function in mitochondrial diseases. Mol Ther 23: 1592-1599, 2015. https://doi.org/10.1038/mt.2015.126

HEJZLAROVÁ K, KAPLANOVÁ V, NŮSKOVÁ H, KOVÁŘOVÁ N, JEŠINA P, DRAHOTA Z, MRÁČEK T, SENECA S, HOUŠTĚK J: Alteration of structure and function of ATP synthase and cytochrome c oxidase by lack of Fo-a and Cox3 subunits caused by mitochondrial DNA 9205delTA mutation. Biochem J 466: 601-611, 2015. https://doi.org/10.1042/BJ20141462

HENZE K, MARTIN W: Evolutionary biology: essence of mitochondria. Nature 426: 127-128, 2003. https://doi.org/10.1038/426127a

HIRANO M, EMMANUELE V, QUINZII CM: Emerging therapies for mitochondrial diseases. Essays Biochem 62: 467-481, 2018. https://doi.org/10.1042/EBC20170114

HOFER A, NOE N, TISCHNER C, KLADT N, LELLEK V, SCHAUß A, WENZ T: Defining the action spectrum of potential PGC-1 $\alpha$ activators on a mitochondrial and cellular level in vivo. Hum Mol Genet 23: 2400-2415, 2014. https://doi.org/10.1093/hmg/ddt631

HOLZEROVA E, DANHAUSER K, HAACK TB, KREMER LS, MELCHER M, INGOLD I, KOBAYASHI S, TERRILE C, WOLF P, SCHAPER J, MAYATEPEK E, BAERTLING F, FRIEDMANN ANGELI JP, CONRAD M, STROM TM, MEITINGER T, PROKISCH H, DISTELMAIER F: Human thioredoxin 2 deficiency impairs mitochondrial redox homeostasis and causes early-onset neurodegeneration. Brain 139: 346-354, 2016. https://doi.org/10.1093/brain/awv350

HOLZEROVÁ E, PROKISCH H: Mitochondria: Much ado about nothing? How dangerous is reactive oxygen species production? Int J Biochem Cell Biol 63: 16-20, 2015. https://doi.org/10.1016/j.biocel.2015.01.021

HORVATH R: Update on clinical aspects and treatment of selected vitamin-responsive disorders II (riboflavin and CoQ 10). J Inherit Metab Dis 35: 679-687, 2012. https://doi.org/10.1007/s10545-011-9434-1 
HSU PD, LANDER ES, ZHANG F: Development and applications of CRISPR-Cas9 for genome engineering. Cell 157: 1262-1278, 2014. https://doi.org/10.1016/j.cell.2014.05.010

HUSSAIN S-RA, YALVAC ME, KHOO B, ECKARDT S, MCLAUGHLIN KJ: Adapting CRISPR/Cas9 system for targeting mitochondrial genome. bioRxiv 2020. https://doi.org/10.1101/2020.02.11.944819

HYSLOP LA, BLAKELEY P, CRAVEN L, RICHARDSON J, FOGARTY NM, FRAGOULI E, LAMB M, WAMAITHA SE, PRATHALINGAM N, ZHANG Q, O'KEEFE H, TAKEDA Y, ARIZZI L, ALFARAWATI S, TUPPEN HA, IRVING L, KALLEAS D, CHOUDHARY M, WELLS D, MURDOCH AP, TURNBULL DM, NIAKAN KK, HERBERT M: Towards clinical application of pronuclear transfer to prevent mitochondrial DNA disease. Nature 534: 383-386, 2016. https://doi.org/10.1038/nature18303

CHATFIELD KC, SPARAGNA GC, CHAU S, PHILLIPS EK, AMBARDEKAR AV, AFTAB M, MITCHELL MB, SUCHAROV CC, MIYAMOTO SD, STAUFFER BL: Elamipretide improves mitochondrial function in the failing human heart. JACC Basic Transl Sci 4: 147-157, 2019. https://doi.org/10.1016/j.jacbts.2018.12.005

CHINNERY PF, TURNBULL DM: Epidemiology and treatment of mitochondrial disorders. Am J Med Genet 106: 94-101, 2001. https://doi.org/10.1002/ajmg. 1426

CHO J, WON K, WU D, SOONG Y, LIU S, SZETO HH, HONG MK: Potent mitochondria-targeted peptides reduce myocardial infarction in rats. Coron Artery Dis 18: 215-220, 2007. https://doi.org/10.1097/01.mca.0000236285.71683.b6

ISHII T, HIBINO Y: Mitochondrial manipulation in fertility clinics: Regulation and responsibility. Reprod Biomed Soc Online 5: 93-109, 2018. https://doi.org/10.1016/j.rbms.2018.01.002

JADIYA P, TOMAR D: Mitochondrial protein quality control mechanisms. Genes (Basel) 11: 2020. https://doi.org/10.3390/genes11050563

JAIN IH, CALVO SE, MARKHARD AL, SKINNER OS, TO TL, AST T, MOOTHA VK: Genetic screen for cell fitness in high or low oxygen highlights mitochondrial and lipid metabolism. Cell 181: 716-727 e711, 2020. https://doi.org/10.1016/j.cell.2020.03.029

JAIN IH, ZAZZERON L, GOLDBERGER O, MARUTANI E, WOJTKIEWICZ GR, AST T, WANG H, SCHLEIFER G, STEPANOVA A, BREPOELS K, SCHOONJANS L, CARMELIET P, GALKIN A, ICHINOSE F, ZAPOL WM, MOOTHA VK: Leigh syndrome mouse model can be rescued by interventions that normalize brain hyperoxia, but not HIF activation. Cell Metab 30: 824-832 e823, 2019. https://doi.org/10.1016/j.cmet.2019.07.006

JAIN IH, ZAZZERON L, GOLI R, ALEXA K, SCHATZMAN-BONE S, DHILLON H, GOLDBERGER O, PENG J, SHALEM O, SANJANA NE, ZHANG F, GOESSLING W, ZAPOL WM, MOOTHA VK: Hypoxia as a therapy for mitochondrial disease. Science 352: 54-61, 2016. https://doi.org/10.1126/science.aad9642

JANSSEN MCH, KOENE S, DE LAAT P, HEMELAAR P, PICKKERS P, SPAANS E, BEUKEMA R, BEYRATH J, GROOTHUIS J, VERHAAK C, SMEITINK J: The KHENERGY Study: Safety and efficacy of KH176 in mitochondrial m.3243A $>\mathrm{G}$ spectrum disorders. Clin Pharmacol Ther 105: 101-111, 2019. https://doi.org/10.1002/cpt.1197

JAUHARI P, SANKHYAN N, VYAS S, SINGHI P: Thiamine responsive pyruvate dehydrogenase complex deficiency: a potentially treatable cause of leigh's disease. J Pediatr Neurosci 12: 265-267, 2017. https://doi.org/10.4103/jpn.JPN_191_16

JEPPESEN TD, DUNØ M, SCHWARTZ M, KRAG T, RAFIQ J, WIBRAND F, VISSING J: Short- and long-term effects of endurance training in patients with mitochondrial myopathy. Eur J Neurol 16: 1336-1339, 2009. https://doi.org/10.1111/j.1468-1331.2009.02660.x

JEPPESEN TD, SCHWARTZ M, OLSEN DB, WIBRAND F, KRAG T, DUNØ M, HAUERSLEV S, VISSING J: Aerobic training is safe and improves exercise capacity in patients with mitochondrial myopathy. Brain 129: 3402-3412, 2006. https://doi.org/10.1093/brain/awl149

JO A, HAM S, LEE GH, LEE YI, KIM S, LEE YS, SHIN JH, LEE Y: Efficient Mitochondrial Genome Editing by CRISPR/Cas9. Biomed Res Int 2015: 305716, 2015. https://doi.org/10.1155/2015/305716

JOHNSON SC, KAEBERLEIN M: Rapamycin in aging and disease: maximizing efficacy while minimizing side effects. Oncotarget 7: 44876-44878, 2016. https://doi.org/10.18632/oncotarget.10381 
JOHNSON SC, YANOS ME, KAYSER EB, QUINTANA A, SANGESLAND M, CASTANZA A, UHDE L, HUI J, WALL VZ, GAGNIDZE A, OH K, WASKO BM, RAMOS FJ, PALMITER RD, RABINOVITCH PS, MORGAN PG, SEDENSKY MM, KAEBERLEIN M: mTOR inhibition alleviates mitochondrial disease in a mouse model of Leigh syndrome. Science 342: 1524-1528, 2013. https://doi.org/10.1126/science.1244360

KADOYA T, SAKAKIBARA A, KITAYAMA K, YAMADA Y, HIGUCHI S, KAWAKITA R, KAWASAKI Y, FUJINO M, MURAKAMI Y, SHIMURA M, MURAYAMA K, OHTAKE A, OKAZAKI Y, KOGA Y, YORIFUJI T: Successful treatment of infantile-onset ACAD9-related cardiomyopathy with a combination of sodium pyruvate, beta-blocker, and coenzyme Q10. J Pediatr Endocrinol Metab 32: 1181-1185, 2019. https://doi.org/10.1515/jpem-2019-0205

KAISER J, SCHRAMEK N, EBERHARDT S, PÜTTMER S, SCHUSTER M, BACHER A: Biosynthesis of vitamin B2. Eur J Biochem 269: 5264-5270, 2002. https://doi.org/10.1046/j.1432-1033.2002.03239.x

KARAA A, HAAS R, GOLDSTEIN A, VOCKLEY J, COHEN BH: A randomized crossover trial of elamipretide in adults with primary mitochondrial myopathy. J Cachexia Sarcopenia Muscle 2020. https://doi.org/10.1002/jcsm.12559

KARAA A, HAAS R, GOLDSTEIN A, VOCKLEY J, WEAVER WD, COHEN BH: Randomized dose-escalation trial of elamipretide in adults with primary mitochondrial myopathy. Neurology 90: e1212-e1221, 2018. https://doi.org/10.1212/WNL.0000000000005255

KARAARSLAN C: Leber's hereditary optic neuropathy as a promising disease for gene therapy development. Adv Ther 36: 3299-3307, 2019. https://doi.org/10.1007/s12325-019-01113-2

KAUFMANN P, ENGELSTAD K, WEI Y, JHUNG S, SANO MC, SHUNGU DC, MILLAR WS, HONG X, GOOCH CL, MAO X, PASCUAL JM, HIRANO M, STACPOOLE PW, DIMAURO S, DE VIVO DC: Dichloroacetate causes toxic neuropathy in MELAS: a randomized, controlled clinical trial. Neurology 66: 324-330, 2006. https://doi.org/10.1212/01.wnl.0000196641.05913.27

KAUR A, SHARMA S: Mammalian target of rapamycin (mTOR) as a potential therapeutic target in various diseases. Inflammopharmacology 25: 293-312, 2017. https://doi.org/10.1007/s10787-017-0336-1

KERR DS: Review of clinical trials for mitochondrial disorders: 1997-2012. Neurotherapeutics 10: 307-319, 2013. https://doi.org/10.1007/s13311-013-0176-7

KHAN NA, AURANEN M, PAETAU I, PIRINEN E, EURO L, FORSSTRÖM S, PASILA L, VELAGAPUDI V, CARROLL CJ, AUWERX J, SUOMALAINEN A: Effective treatment of mitochondrial myopathy by

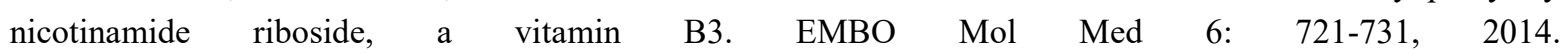
https://doi.org/10.1002/emmm.201403943

KHAN NA, NIKKANEN J, YATSUGA S, JACKSON C, WANG L, PRADHAN S, KIVELÄ R, PESSIA A, VELAGAPUDI V, SUOMALAINEN A: mTORC1 regulates mitochondrial integrated stress response and mitochondrial myopathy progression. Cell Metab 26: 419-428.e415, 2017. https://doi.org/10.1016/j.cmet.2017.07.007

KLOPSTOCK T, METZ G, YU-WAI-MAN P, BÜCHNER B, GALLENMÜLLER C, BAILIE M, NWALI N, GRIFFITHS PG, VON LIVONIUS B, REZNICEK L, ROULEAU J, COPPARD N, MEIER T, CHINNERY PF: Persistence of the treatment effect of idebenone in Leber's hereditary optic neuropathy. Brain 136: e230, 2013. https://doi.org/10.1093/brain/aws279

KLOPSTOCK T, YU-WAI-MAN P, DIMITRIADIS K, ROULEAU J, HECK S, BAILIE M, ATAWAN A, CHATTOPADHYAY S, SCHUBERT M, GARIP A, KERNT M, PETRAKI D, RUMMEY C, LEINONEN M, METZ G, GRIFFITHS PG, MEIER T, CHINNERY PF: A randomized placebo-controlled trial of idebenone in Leber's hereditary optic neuropathy. Brain 134: 2677-2686, 2011. https://doi.org/10.1093/brain/awr170

KOENE S, SMEITINK JAM: Mitochondrial medicine: a clinical guideline, Nijmegen, The Netherlands, Khondrion BV, 2011. https://doi.org/10.1007/s10545-011-9292-X

KOENE S, SPAANS E, VAN BORTEL L, VAN LANCKER G, DELAFONTAINE B, BADILINI F, BEYRATH J, SMEITINK J: KH176 under development for rare mitochondrial disease: a first in man randomized controlled clinical trial in healthy male volunteers. Orphanet J Rare Dis 12: 163, 2017. https://doi.org/10.1186/s13023$\underline{017-0715-0}$ 
KREMER LS, DANHAUSER K, HEREBIAN D, PETKOVIC RAMADŽA D, PIEKUTOWSKA-ABRAMCZUK D, SEIBT A, MÜLLER-FELBER W, HAACK TB, PŁOSKI R, LOHMEIER K, SCHNEIDER D, KLEE D, ROKICKI D, MAYATEPEK E, STROM TM, MEITINGER T, KLOPSTOCK T, PRONICKA E, MAYR JA, BARIC I, DISTELMAIER F, PROKISCH H: NAXE Mutations Disrupt the Cellular NAD(P)HX Repair System and Cause a Lethal Neurometabolic Disorder of Early Childhood. Am J Hum Genet 99: 894-902, 2016. https://doi.org/10.1016/j.ajhg.2016.07.018

KRIPPS K, NAKAYUENYONGSUK W, SHAYOTA BJ, BERQUIST W, GOMEZ-OSPINA N, ESQUIVEL CO, CONCEPCION W, SAMPSON JB, CRISTIN DJ, JACKSON WE, GILLILAND S, POMFRET EA, KUEHT ML, PETTIT RW, SHERIF YA, EMRICK LT, ELSEA SH, HIMES R, HIRANO M, VAN HOVE JLK, SCAGLIA F, ENNS GM, LARSON AA: Successful liver transplantation in mitochondrial neurogastrointestinal encephalomyopathy (MNGIE). Mol Genet Metab 130: 58-64, 2020. https://doi.org/10.1016/j.ymgme.2020.03.001

KWONG AK, CHIU AT, TSANG MH, LUN KS, RODENBURG RJT, SMEITINK J, CHUNG BH, FUNG CW: A fatal case of COQ7-associated primary coenzyme Q(10) deficiency. JIMD Rep 47: 23-29, 2019. https://doi.org/10.1002/jmd2.12032

LAKE NJ, COMPTON AG, RAHMAN S, THORBURN DR: Leigh syndrome: One disorder, more than 75 monogenic causes. Ann Neurol 79: 190-203, 2016. https://doi.org/10.1002/ana.24551

LAMMING DW, YE L, SABATINI DM, BAUR JA: Rapalogs and mTOR inhibitors as anti-aging therapeutics. J Clin Invest 123: 980-989, 2013. https://doi.org/10.1172/JCI64099

LAURITZEN KH, HASAN-OLIVE MM, REGNELL CE, KLEPPA L, SCHEIBYE-KNUDSEN M, GJEDDE A, KLUNGLAND A, BOHR VA, STORM-MATHISEN J, BERGERSEN LH: A ketogenic diet accelerates neurodegeneration in mice with induced mitochondrial DNA toxicity in the forebrain. Neurobiol Aging 48: 34-47, 2016. https://doi.org/10.1016/j.neurobiolaging.2016.08.005

LIENHART WD, GUDIPATI V, MACHEROUX P: The human flavoproteome. Arch Biochem Biophys 535: 150-162, 2013. https://doi.org/10.1016/j.abb.2013.02.015

LIGHTOWLERS RN, TAYLOR RW, TURNBULL DM: Mutations causing mitochondrial disease: What is new and what challenges remain? Science 349: 1494-1499, 2015. https://doi.org/10.1126/science.aac7516

LOPEZ-GOMEZ C, LEVY RJ, SANCHEZ-QUINTERO MJ, JUANOLA-FALGARONA M, BARCA E, GARCIADIAZ B, TADESSE S, GARONE C, HIRANO M: Deoxycytidine and Deoxythymidine Treatment for Thymidine Kinase 2 Deficiency. Ann Neurol 81: 641-652, 2017. https://doi.org/10.1002/ana.24922

LYSENG-WILLIAMSON KA: Idebenone: A review in leber's hereditary optic neuropathy. Drugs 76: 805-813, 2016. https://doi.org/10.1007/s40265-016-0574-3

MADHOK J, LEONG J, COHN J: Anesthetic Considerations for Liver Transplantation in a Patient with Mitochondrial Neurogastrointestinal Encephalopathy Syndrome. Cureus 11: e5038, 2019. https://doi.org/10.7759/cureus.5038

MAGALHÃES PV, DEAN O, ANDREAZZA AC, BERK M, KAPCZINSKI F: Antioxidant treatments for schizophrenia. Cochrane Database Syst Rev 2: $\quad$ Cd008919, 2016. https://doi.org/10.1002/14651858.CD008919.pub2

MAJAMAA K, RUSANEN H, REMES AM, PYHTINEN J, HASSINEN IE: Increase of blood NAD+ and attenuation of lactacidemia during nicotinamide treatment of a patient with the MELAS syndrome. Life Sci 58: 691-699, 1996. https://doi.org/10.1016/S0024-3205(96)80008-7

MANCUSO M, ANGELINI C, BERTINI E, CARELLI V, COMI GP, MINETTI C, MOGGIO M, MONGINI T, SERVIDEI S, TONIN P, TOSCANO A, UZIEL G, ZEVIANI M, SICILIANO G: Fatigue and exercise intolerance in mitochondrial diseases. Literature revision and experience of the Italian Network of mitochondrial diseases. Neuromuscul Disord $22 \quad$ (Suppl 3): $\quad$ S226-229, 2012. https://doi.org/10.1016/j.nmd.2012.10.012

MARCÉ-GRAU A, MARTÍ-SÁNCHEZ L, BAIDE-MAIRENA H, ORTIGOZA-ESCOBAR JD, PÉREZ-DUEÑAS B: Genetic defects of thiamine transport and metabolism: A review of clinical phenotypes, genetics, and functional studies. J Inherit Metab Dis 42: 581-597, 2019. https://doi.org/10.1002/jimd.12125

MARSHALL KG: Exploring antioxidants. West Indian Med J 63: 119-120, 2014. 
MAYR JA, HAACK TB, FREISINGER P, KARALL D, MAKOWSKI C, KOCH J, FEICHTINGER RG, ZIMMERMANN FA, ROLINSKI B, AHTING U, MEITINGER T, PROKISCH H, SPERL W: Spectrum of combined respiratory chain defects. J Inherit Metab Dis 38: 629-640, 2015. https://doi.org/10.1007/s10545015-9831-y

MCCANN BJ, COX A, GAMMAGE PA, STEWART JB, ZERNICKA-GOETZ M, MINCZUK M: Delivery of mtZFNs into Early Mouse Embryos. Methods Mol Biol 1867: 215-228, 2018. https://doi.org/10.1007/978-14939-8799-3 16

MILLER SA, DYMSZA HA: Utilization by the rat of 1,3-butanediol as a synthetic source of dietary energy. J Nutr 91: 79-88, 1967. https://doi.org/10.1093/jn/91.1.79

MOSTER M, SADUN A, KLOPSTOCK T, NEWMAN N, VIGNAL-CLERMONT C, CARELLI V, YU-WAI-MAN P, BIOUSSE V, SERGOTT R, KATZ B, DEBUSK A, BLOUIN L, CHEVALIER C, BURGUIERE P, TAIEL M, SAHEL JA: rAAV2/2-ND4 for the Treatment of Leber Hereditary Optic Neuropathy (LHON): Final Results from the RESCUE and REVERSE Phase III Clinical Trials and Experimental Data in Nonhuman Primates to Support a Bilateral Effect (2339). Neurology 2020.

MUNNICH A, RUSTIN P: Clinical spectrum and diagnosis of mitochondrial disorders. Am J Med Genet 106: 4-17, 2001. https://doi.org/10.1002/ajmg.1391

MURPHY JL, BLAKELY EL, SCHAEFER AM, HE L, WYRICK P, HALLER RG, TAYLOR RW, TURNBULL DM, TAIVASSALO T: Resistance training in patients with single, large-scale deletions of mitochondrial DNA. Brain 131: 2832-2840, 2008. https://doi.org/10.1093/brain/awn252

MURU K, REINSON K, KÜNNAPAS K, LILLEVÄLI H, NOCHI Z, MOSEGAARD S, PAJUSALU S, OLSEN RKJ, ÕUNAP K: FLAD1-associated multiple acyl-CoA dehydrogenase deficiency identified by newborn screening. Mol Genet Genomic Med 7: e915, 2019. https://doi.org/10.1002/mgg3.915

NUSKOVA H, MIKESOVA J, EFIMOVA I, PECINOVA A, PECINA P, DRAHOTA Z, HOUSTEK J, MRACEK T: Biochemical thresholds for pathological presentation of ATP synthase deficiencies. Biochem Biophys Res Commun 521: 1036-1041, 2020. https://doi.org/10.1016/j.bbrc.2019.11.033

O'DAY SJ, EGGERMONT AM, CHIARION-SILENI V, KEFFORD R, GROB JJ, MORTIER L, ROBERT C, SCHACHTER J, TESTORI A, MACKIEWICZ J, FRIEDLANDER P, GARBE C, UGUREL S, COLLICHIO F, GUO W, LUFKIN J, BAHCALL S, VUKOVIC V, HAUSCHILD A: Final results of phase III SYMMETRY study: randomized, double-blind trial of elesclomol plus paclitaxel versus paclitaxel alone as treatment for chemotherapy-naive patients with advanced melanoma. J Clin Oncol 31: 1211-1218, 2013. https://doi.org/10.1200/JCO.2012.44.5585

OLSEN RK, OLPIN SE, ANDRESEN BS, MIEDZYBRODZKA ZH, POURFARZAM M, MERINERO B, FRERMAN FE, BERESFORD MW, DEAN JC, CORNELIUS N, ANDERSEN O, OLDFORS A, HOLME E, GREGERSEN N, TURNBULL DM, MORRIS AA: ETFDH mutations as a major cause of riboflavinresponsive multiple acyl-CoA dehydrogenation deficiency. Brain 130: 2045-2054, 2007. https://doi.org/10.1093/brain/awm135

OLSEN RKJ, KOŇAŘÍKOVÁ E, GIANCASPERO TA, MOSEGAARD S, BOCZONADI V, MATAKOVIĆ L, VEAUVILLE-MERLLIÉ A, TERRILE C, SCHWARZMAYR T, HAACK TB, AURANEN M, LEONE P, GALLUCCIO M, IMBARD A, GUTIERREZ-RIOS P, PALMFELDT J, GRAF E, VIANEY-SABAN C, OPPENHEIM M, SCHIFF M, PICHARD S, RIGAL O, PYLE A, CHINNERY PF, KONSTANTOPOULOU V, MÖSLINGER D, FEICHTINGER RG, TALIM B, TOPALOGLU H, COSKUN T, GUCER S, BOTTA A, PEGORARO E, MALENA A, VERGANI L, MAZZÀ D, ZOLLINO M, GHEZZI D, ACQUAVIVA C, TYNI T, BONEH A, MEITINGER T, STROM TM, GREGERSEN N, MAYR JA, HORVATH R, BARILE M, PROKISCH H: Riboflavin-responsive and -non-responsive mutations in FAD synthase cause multiple acylCoA dehydrogenase and combined respiratory-chain deficiency. Am J Hum Genet 98: 1130-1145, 2016. https://doi.org/10.1016/j.ajhg.2016.04.006

ØRNGREEN MC, MADSEN KL, PREISLER N, ANDERSEN G, VISSING J, LAFORÊT P: Bezafibrate in skeletal muscle fatty acid oxidation disorders: a randomized clinical trial. Neurology 82: 607-613, 2014. https://doi.org/10.1212/WNL.0000000000000118 
ORTIGOZA-ESCOBAR JD, MOLERO-LUIS M, ARIAS A, MARTÍ-SÁNCHEZ L, RODRIGUEZ-POMBO P, ARTUCH R, PÉREZ-DUEÑAS B: Treatment of genetic defects of thiamine transport and metabolism. Expert Rev Neurothe 16: 755-763, 2016. https://doi.org/10.1080/14737175.2016.1187562

PAN J, WANG L, LU C, ZHU Y, MIN Z, DONG X, SHA H: Matching Mitochondrial DNA Haplotypes for Circumventing Tissue-Specific Segregation Bias. iScience 13: $371-379,2019$. https://doi.org/10.1016/j.isci.2019.03.002

PARIKH S, SANETO R, FALK MJ, ANSELM I, COHEN BH, HAAS R, MEDICINE SOCIETY TM: A modern approach to the treatment of mitochondrial disease. Curr Treat Options Neurol 11: 414-430, 2009. https://doi.org/10.1007/s11940-009-0046-0

PATGIRI A, SKINNER OS, MIYAZAKI Y, SCHLEIFER G, MARUTANI E, SHAH H, SHARMA R, GOODMAN RP, TO TL, ROBERT BAO X, ICHINOSE F, ZAPOL WM, MOOTHA VK: An engineered enzyme that targets circulating lactate to alleviate intracellular NADH:NAD(+) imbalance. Nat Biotechnol 38: 309-313, 2020. https://doi.org/10.1038/s41587-019-0377-7

PERALTA S, GARCIA S, YIN HY, ARGUELLO T, DIAZ F, MORAES CT: Sustained AMPK activation improves muscle function in a mitochondrial myopathy mouse model by promoting muscle fiber regeneration. Hum Mol Genet 25: 3178-3191, 2016. https://doi.org/10.1093/hmg/ddw167

PEREIRA CV, BACMAN SR, ARGUELLO T, ZEKONYTE U, WILLIAMS SL, EDGELL DR, MORAES CT: mitoTev-TALE: a monomeric DNA editing enzyme to reduce mutant mitochondrial DNA levels. EMBO Mol Med 10: 2018. https://doi.org/10.15252/emmm.201708084

PEREIRA CV, MORAES CT: Current strategies towards therapeutic manipulation of mtDNA heteroplasmy. Front Biosci (Landmark Ed) 22: 991-1010, 2017. https://doi.org/10.2741/4529

PÉREZ-DUEÑAS B, SERRANO M, REBOLLO M, MUCHART J, GARGALLO E, DUPUITS C, ARTUCH R: Reversible lactic acidosis in a newborn with thiamine transporter-2 deficiency. Pediatrics 131: e1670-1675, 2013. https://doi.org/10.1542/peds.2012-2988

PFEFFER G, MAJAMAA K, TURNBULL DM, THORBURN D, CHINNERY PF: Treatment for mitochondrial disorders. Cochrane Database Syst Rev, Cd004426, 2012. https://doi.org/10.1002/14651858.CD004426.pub3

PHILLIPS IR, SHEPHARD EA: Primary Trimethylaminuria. In: ADAM, M. P., ARDINGER, H. H., PAGON, R. A., WALLACE SE, BEAN LJH, STEPHENS K, AMEMIYA A (eds.) GeneReviews(®). University of Washington, Seattle (WA), 1993-2020. https://www.ncbi.nlm.nih.gov/books/NBK1103/

PIRINEN E, AURANEN M, KHAN NA, BRILHANTE V, URHO N, PESSIA A, HAKKARAINEN A, KUULA J, HEINONEN U, SCHMIDT MS, HAIMILAHTI K, PIIRILÄ P, LUNDBOM N, TASKINEN MR, BRENNER C, VELAGAPUDI V, PIETILÄINEN KH, SUOMALAINEN A: Niacin cures systemic NAD(+) deficiency and improves muscle performance in adult-onset mitochondrial myopathy. Cell Metab: 2020. https://doi.org/10.1016/j.cmet.2020.05.020

POMAHAČOVÁ R, ZAMBORYOVÁ J, SÝKORA J, PATEROVÁ P, FIKLÍK K, VOTAVA T, ČERNÁ Z, JEHLIČKA P, LÁD V, ŠUBRT I, DORT J, DORTOVÁ E: First 2 cases with thiamine-responsive megaloblastic anemia in the Czech Republic, a rare form of monogenic diabetes mellitus: a novel mutation in the thiamine transporter SLC19A2 gene-intron 1 mutation c.204+2T>G. Pediatr Diabetes 18: 844-847, 2017. https://doi.org/10.1111/pedi.12479

PORCELLI S, MARZORATI M, MORANDI L, GRASSI B: Home-based aerobic exercise training improves skeletal muscle oxidative metabolism in patients with metabolic myopathies. J Appl Physiol (1985), 121, 699-708, 2016. https://doi.org/10.1152/japplphysiol.00885.2015

POTGIETER M, PRETORIUS E, PEPPER MS: Primary and secondary coenzyme Q10 deficiency: the role of therapeutic supplementation. Nutr Rev 71: 180-188, 2013. https://doi.org/10.1111/nure.12011

PURHONEN J, RAJENDRAN J, MÖRGELIN M, UUSI-RAUVA K, KATAYAMA S, KRJUTSKOV K, EINARSDOTTIR E, VELAGAPUDI V, KERE J, JAUHIAINEN M, FELLMAN V, KALLIJÄRVI J: Ketogenic diet attenuates hepatopathy in mouse model of respiratory chain complex III deficiency caused by a Bcs11 mutation. Sci Rep 7: 957, 2017. https://doi.org/10.1038/s41598-017-01109-4

RAHMAN J, RAHMAN S: Mitochondrial medicine in the omics era. Lancet 391: 2560-2574, 2018. https://doi.org/10.1016/S0140-6736(18)30727-X 
REARDON S: US panel greenlights creation of male 'three-person' embryos. Nature 530: $142,2016$. https://doi.org/10.1038/nature.2016.19290

REDDY PH, MANCZAK M, KANDIMALLA R: Mitochondria-targeted small molecule SS31: a potential candidate for the treatment of Alzheimer's disease. Hum Mol Genet 26: 1597, 2017. https://doi.org/10.1093/hmg/ddx129

REPP BM, MASTANTUONO E, ALSTON CL, SCHIFF M, HAACK TB, RÖTIG A, ARDISSONE A, LOMBÈS A, CATARINO CB, DIODATO D, SCHOTTMANN G, POULTON J, BURLINA A, JONCKHEERE A, MUNNICH A, ROLINSKI B, GHEZZI D, ROKICKI D, WELLESLEY D, MARTINELLI D, WENHONG D, LAMANTEA E, OSTERGAARD E, PRONICKA E, PIERRE G, SMEETS HJM, WITTIG I, SCURR I, DE COO IFM, MORONI I, SMET J, MAYR JA, DAI L, DE MEIRLEIR L, SCHUELKE M, ZEVIANI M, MORSCHER RJ, MCFARLAND R, SENECA S, KLOPSTOCK T, MEITINGER T, WIELAND T, STROM TM, HERBERG U, AHTING U, SPERL W, NASSOGNE MC, LING H, FANG F, FREISINGER P, VAN COSTER R, STRECKER V, TAYLOR RW, HÄBERLE J, VOCKLEY J, PROKISCH H, WORTMANN S: Clinical, biochemical and genetic spectrum of 70 patients with ACAD9 deficiency: is riboflavin supplementation effective? Orphanet J Rare Dis 13: 120, 2018. https://doi.org/10.1186/s13023-018-0784-8

RICH P: Chemiosmotic coupling: The cost of living. Nature 421: 583, 2003. https://doi.org/10.1038/421583a

ROBERTS MN, WALLACE MA, TOMILOV AA, ZHOU Z, MARCOTTE GR, TRAN D, PEREZ G, GUTIERREZCASADO E, KOIKE S, KNOTTS TA, IMAI DM, GRIFFEY SM, KIM K, HAGOPIAN K, MCMACKIN MZ, HAJ FG, BAAR K, CORTOPASSI GA, RAMSEY JJ, LOPEZ-DOMINGUEZ JA: A ketogenic diet extends longevity and healthspan in adult mice. Cell Metab 26: 539-546.e535, 2017. https://doi.org/10.1016/j.cmet.2017.08.005

ROMERO-MOYA D, CASTAÑO J, SANTOS-OCAÑA C, NAVAS P, MENENDEZ P: Generation, genome edition and characterization of iPSC lines from a patient with coenzyme Q(10) deficiency harboring a heterozygous mutation in COQ4 gene. Stem Cell Res 24: 144-147, 2017. https://doi.org/10.1016/j.scr.2016.09.007

RUDOLPH G, DIMITRIADIS K, BÜCHNER B, HECK S, AL-TAMAMI J, SEIDENSTICKER F, RUMMEY C, LEINONEN M, MEIER T, KLOPSTOCK T: Effects of idebenone on color vision in patients with leber hereditary optic neuropathy. J Neuroophthalmol 33: $30-36, \quad 2013$. https://doi.org/10.1097/WNO.0b013e318272c643

RUSKIN DN, ROSS JL, KAWAMURA M, Jr., RUIZ TL, GEIGER JD, MASINO SA: A ketogenic diet delays weight loss and does not impair working memory or motor function in the R6/2 $1 \mathrm{~J}$ mouse model of Huntington's disease. Physiol Behav 103: 501-507, 2011. https://doi.org/10.1016/j.physbeh.2011.04.001

RUSSELL OM, GORMAN GS, LIGHTOWLERS RN, TURNBULL DM: Mitochondrial Diseases: Hope for the Future. Cell, 181, 168-188, 2020. https://doi.org/10.1016/j.cell.2020.02.051

SAADA A: Insights into deoxyribonucleoside therapy for mitochondrial TK2 deficient mtDNA depletion. EBioMedicine 47: 14-15, 2019. https://doi.org/10.1016/j.ebiom.2019.08.005

SAFDAR A, BOURGEOIS JM, OGBORN DI, LITTLE JP, HETTINGA BP, AKHTAR M, THOMPSON JE, MELOV S, MOCELLIN NJ, KUJOTH GC, PROLLA TA, TARNOPOLSKY MA: Endurance exercise rescues progeroid aging and induces systemic mitochondrial rejuvenation in mtDNA mutator mice. Proc Natl Acad Sci U S A 108: 4135-4140, 2011. https://doi.org/10.1073/pnas.1019581108

SAFDAR A, SALEEM A, TARNOPOLSKY MA: The potential of endurance exercise-derived exosomes to treat metabolic diseases. Nat Rev Endocrinol 12: 504-517, 2016. https://doi.org/10.1038/nrendo.2016.76

SAGE-SCHWAEDE A, ENGELSTAD K, SALAZAR R, CURCIO A, KHANDJI A, GARVIN JH Jr., DE VIVO DC: Exploring mTOR inhibition as treatment for mitochondrial disease. Ann Clin Transl Neurol 6: 1877-1881, 2019. https://doi.org/10.1002/acn3.50846

SAMUELS DC, WONNAPINIJ P, CHINNERY PF: Preventing the transmission of pathogenic mitochondrial DNA mutations: Can we achieve long-term benefits from germ-line gene transfer? Hum Reprod 28: 554-559, 2013. https://doi.org/10.1093/humrep/des439

SANTRA S, GILKERSON RW, DAVIDSON M, SCHON EA: Ketogenic treatment reduces deleted mitochondrial DNAs in cultured human cells. Ann Neurol 56: 662-669, 2004. https://doi.org/10.1002/ana.20240 
SATO Y, NAKAGAWA M, HIGUCHI I, OSAME M, NAITO E, OIZUMI K: Mitochondrial myopathy and familial thiamine deficiency. Muscle Nerve 23: 1069-1075, 2000. https://doi.org/10.1002/10974598(200007)23:7<1069::AID-MUS9>3.0.CO;2-0

SCIACCO M, BONILLA E, SCHON EA, DIMAURO S, MORAES CT: Distribution of wild-type and common deletion forms of mtDNA in normal and respiration-deficient muscle fibers from patients with mitochondrial myopathy. Hum Mol Genet 3: 13-19, 1994. https://doi.org/10.1093/hmg/3.1.13

SCHLEIFER G, MARUTANI E, FERRARI M, SHARMA R, SKINNER O, GOLDBERGER O, GRANGE RMH, PENEYRA K, MALHOTRA R, WEPLER M, ICHINOSE F, BLOCH DB, MOOTHA VK, ZAPOL WM: Impaired hypoxic pulmonary vasoconstriction in a mouse model of Leigh syndrome. Am J Physiol Lung Cell Mol Physiol 316: L391-L399, 2019. https://doi.org/10.1152/ajplung.00419.2018

SCHOLL-BÜRGI S, HÖLLER A, PICHLER K, MICHEL M, HABERLANDT E, KARALL D: Ketogenic diets in patients with inherited metabolic disorders. $J$ Inherit Metab Dis 38: 765-773, 2015. https://doi.org/10.1007/s10545-015-9872-2

SIEGMUND SE, YANG H, SHARMA R, JAVORS M, SKINNER O, MOOTHA V, HIRANO M, SCHON EA: Low-dose rapamycin extends lifespan in a mouse model of mtDNA depletion syndrome. Hum Mol Genet 26: 4588-4605, 2017. https://doi.org/10.1093/hmg/ddx341

SMEITINK JA: Mitochondrial disorders: clinical presentation and diagnostic dilemmas. J Inherit Metab Dis 26 : 199-207, 2003. https://doi.org/10.1023/A:1024489218004

SOMA S, LATIMER AJ, CHUN H, VICARY AC, TIMBALIA SA, BOULET A, RAHN JJ, CHAN SSL, LEARY SC, KIM BE, GITLIN JD, GOHIL VM: Elesclomol restores mitochondrial function in genetic models of copper deficiency. Proc Natl Acad Sci U S A 115: 8161-8166, 2018. https://doi.org/10.1073/pnas.1806296115

SRIVASTAVA S, DIAZ F, IOMMARINI L, AURE K, LOMBES A, MORAES CT: PGC-1alpha/beta induced expression partially compensates for respiratory chain defects in cells from patients with mitochondrial disorders. Hum Mol Genet 18: 1805-1812, 2009. https://doi.org/10.1093/hmg/ddp093

STACPOOLE PW, MARTYNIUK CJ, JAMES MO, CALCUTT NA: Dichloroacetate-induced peripheral neuropathy. Int Rev Neurobiol 145: 211-238, 2019. https://doi.org/10.1016/bs.irn.2019.05.003

STEELE H, GOMEZ-DURAN A, PYLE A, HOPTON S, NEWMAN J, STEFANETTI RJ, CHARMAN SJ, PARIKH JD, HE L, VISCOMI C, JAKOVLJEVIC DG, HOLLINGSWORTH KG, ROBINSON AJ, TAYLOR RW, BOTTOLO L, HORVATH R, CHINNERY PF: Metabolic effects of bezafibrate in mitochondrial disease. EMBO Mol Med 12: e11589, 2020. https://doi.org/10.15252/emmm.201911589

STENTON SL, PROKISCH H: Advancing genomic approaches to the molecular diagnosis of mitochondrial disease. Essays Biochem 62: 399-408, 2018. https://doi.org/10.1042/EBC20170110

STENTON SL, PROKISCH H: Genetics of mitochondrial diseases: Identifying mutations to help diagnosis. EBioMedicine 56: 102784, 2020. https://doi.org/10.1016/j.ebiom.2020.102784

STEWART JB, CHINNERY PF: The dynamics of mitochondrial DNA heteroplasmy: implications for human health and disease. Nat Rev Genet 16: 530-542, 2015. https://doi.org/10.1038/nrg3966

SUOMALAINEN A, BATTERSBY BJ: Mitochondrial diseases: the contribution of organelle stress responses to pathology. Nat Rev Mol Cell Biol 19: 77-92, 2018. https://doi.org/10.1038/nrm.2017.66

TAIVASSALO T, GARDNER JL, TAYLOR RW, SCHAEFER AM, NEWMAN J, BARRON MJ, HALLER RG, TURNBULL DM: Endurance training and detraining in mitochondrial myopathies due to single large-scale mtDNA deletions. Brain 129: 3391-3401, 2006. https://doi.org/10.1093/brain/awl282

TAIVASSALO T, JENSEN TD, KENNAWAY N, DIMAURO S, VISSING J, HALLER RG: The spectrum of exercise tolerance in mitochondrial myopathies: a study of 40 patients. Brain 126: 413-423, 2003. https://doi.org/10.1093/brain/awg028

TAM A, ALDHAHERI NS, MYSORE K, TESSIER ME, GOSS J, FERNANDEZ LA, D'ALESSANDRO AM, SCHWOERER JS, RICE GM, ELSEA SH, SCAGLIA F: Improved clinical outcome following liver transplant in patients with ethylmalonic encephalopathy. Am J Med Genet A 179: 1015-1019, 2019. https://doi.org/10.1002/ajmg.a.61104

TAN EY, BOELENS JJ, JONES SA, WYNN RF: Hematopoietic Stem Cell Transplantation in Inborn Errors of Metabolism. Front Pediatr 7: 433, 2019. https://doi.org/10.3389/fped.2019.00433 
TANAKA M, BORGELD HJ, ZHANG J, MURAMATSU S, GONG JS, YONEDA M, MARUYAMA W, NAOI M, IBI T, SAHASHI K, SHAMOTO M, FUKU N, KURATA M, YAMADA Y, NISHIZAWA K, AKAO Y, OHISHI N, MIYABAYASHI S, UMEMOTO H, MURAMATSU T, FURUKAWA K, KIKUCHI A, NAKANO I, OZAWA K, YAGI K: Gene therapy for mitochondrial disease by delivering restriction endonuclease SmaI into mitochondria. J Biomed Sci 9: 534-541, 2002. https://doi.org/10.1007/BF02254980

TAYLOR RW, TURNBULL DM: Mitochondrial DNA mutations in human disease. Nat Rev Genet 6: 389-402, 2005. https://doi.org/10.1038/nrg1606

THORBURN DR: Mitochondrial disorders: prevalence, myths and advances. J Inherit Metab Dis 27: 349-362, 2004. https://doi.org/10.1023/B:BOLI.0000031098.41409.55

TIRANTI V, VISCOMI C, HILDEBRANDT T, DI MEO I, MINERI R, TIVERON C, LEVITT MD, PRELLE A, FAGIOLARI G, RIMOLDI M, ZEVIANI M: Loss of ETHE1, a mitochondrial dioxygenase, causes fatal sulfide toxicity in ethylmalonic encephalopathy. Nat Med 15: 200-205, 2009. https://doi.org/10.1038/nm.1907

TONON C, LODI R: Idebenone in Friedreich's ataxia. Expert Opin Pharmacother 9 2327-2337, 2008. https://doi.org/10.1517/14656566.9.13.2327

TRINH J, IMHOFF S, DULOVIC-MAHLOW M, KANDASWAMY KK, TADIC V, SCHÄFER J, DOBRICIC V, NOLTE A, WERBER M, ROLFS A, MÜNCHAU A, KLEIN C, LOHMANN K, BRÜGGEMANN N: Novel NAXE variants as a cause for neurometabolic disorder: implications for treatment. J Neurol 267: 770-782, 2020. https://doi.org/10.1007/s00415-019-09640-2

VAN DER AUWERA I, WERA S, VAN LEUVEN F, HENDERSON ST: A ketogenic diet reduces amyloid beta 40 and 42 in a mouse model of Alzheimer's disease. Nutr Metab (Lond) 2: 28, 2005. https://doi.org/10.1186/17437075-2-28

VOET D, PRATT CW, VOET JG: Principles of Biochemistry, John Wiley \& Sons, Inc., 2013.

WAN X, PEI H, ZHAO MJ, YANG S, HU WK, HE H, MA SQ, ZHANG G, DONG XY, CHEN C, WANG DW, LI B: Efficacy and Safety of rAAV2-ND4 Treatment for Leber's Hereditary Optic Neuropathy. Sci Rep 6: 21587, 2016. https://doi.org/10.1038/srep21587

WANG D, GAO G: State-of-the-art human gene therapy: part II. Gene therapy strategies and clinical applications. Discov Med 18: 151-161, 2014.

WEISSIG V: Drug development for the therapy of mitochondrial diseases. Trends Mol Med 26: 40-57, 2020. https://doi.org/10.1016/j.molmed.2019.09.002

WIJERMARS LG, SCHAAPHERDER AF, DE VRIES DK, VERSCHUREN L, WÜST RC, KOSTIDIS S, MAYBORODA OA, PRINS F, RINGERS J, BIERAU J, BAKKER JA, KOOISTRA T, LINDEMAN JH: Defective postreperfusion metabolic recovery directly associates with incident delayed graft function. Kidney Int 90: 181-191, 2016. https://doi.org/10.1016/j.kint.2016.02.034

WU H, LI X, SHEN C: Peroxisome proliferator-activated receptor gamma in white and brown adipocyte regulation and differentiation. Physiol Res 69: 759-773, 2020. https://doi.org/10.33549/physiolres.934371

YANG S, MA SQ, WAN X, HE H, PEI H, ZHAO MJ, CHEN C, WANG DW, DONG XY, YUAN JJ, LI B: Long-term outcomes of gene therapy for the treatment of Leber's hereditary optic neuropathy. EBioMedicine 10: 258-268, 2016. https://doi.org/10.1016/j.ebiom.2016.07.002

YU-WAI-MAN P, GRIFFITHS PG, BROWN DT, HOWELL N, TURNBULL DM, CHINNERY PF: The epidemiology of Leber hereditary optic neuropathy in the North East of England. Am J Hum Genet 72: 333-339, 2003. https://doi.org/10.1086/346066

YU-WAI-MAN P, TURNBULL DM, CHINNERY PF: Leber hereditary optic neuropathy. J Med Genet 39: 162-169, 2002. https://doi.org/10.1136/jmg.39.3.162

YUDKOFF M, DAIKHIN Y, MELØ TM, NISSIM I, SONNEWALD U, NISSIM I: The ketogenic diet and brain metabolism of amino acids: relationship to the anticonvulsant effect. Annu Rev Nutr 27: 415-430, 2007. https://doi.org/10.1146/annurev.nutr.27.061406.093722

ZHANG J, LIU H, LUO S, LU Z, CHÁVEZ-BADIOLA A, LIU Z, YANG M, MERHI Z, SILBER SJ, MUNNÉ S, KONSTANTINIDIS M, WELLS D, TANG JJ, HUANG T: Live birth derived from oocyte spindle transfer to prevent mitochondrial disease. Reprod Biomed Online 34: 361-368, 2017. https://doi.org/10.1016/j.rbmo.2017.01.013 
ZHANG Y, ZHOU S, ZHOU Y, YU L, ZHANG L, WANG Y: Altered gut microbiome composition in children with refractory epilepsy after ketogenic diet. Epilepsy Res 145: 163-168, 2018. https://doi.org/10.1016/j.eplepsyres.2018.06.015

ZHAO K, ZHAO GM, WU D, SOONG Y, BIRK AV, SCHILLER PW, SZETO HH: Cell-permeable peptide antioxidants targeted to inner mitochondrial membrane inhibit mitochondrial swelling, oxidative cell death, and reperfusion injury. J Biol Chem 279: 34682-34690, 2004. https://doi.org/10.1074/jbc.M402999200

ZIAALDINI MM, HOSSEINI SR, FATHI M: Mitochondrial adaptations in aged skeletal muscle: effect of exercise training. Physiol Res 66: 1-14, 2017. https://doi.org/10.33549/physiolres.933329 